\title{
Asymmetric Route to Pyridines Bearing a Highly Functionalized 2-Alkyl Substituent by
} Aziridine Ring Opening Reactions

\author{
Giuseppe Alvaro, $\uparrow$ Romano Di Fabio, $\dagger$ Andrea Gualandi $\ddagger$ and Diego Savoia*, $\ddagger$ \\ $\dagger$ Psychiatric Centre of Excellence for Drug Discovery, GlaxoSmithKline S.p.A., via Fleming 4, 37135 \\ Verona, Italy \\ ¥Dipartimento di Chimica "G. Ciamician", Università di Bologna, via Selmi 2, 40126 Bologna, Italy \\ * Corresponding author. Fax: +39-051-2099456; e-mail address: diego.savoia@ unibo.it
}

\section{List of content:}

Copy of the ${ }^{1} \mathrm{H}$ NMR and ${ }^{13}$ CNMR spectrum for the aminoalchols 2a-i: S2-S19

Copy of the ${ }^{1} \mathrm{H}$ NMR and ${ }^{13}$ CNMR spectrum for the aminoalchols 3a-h: S20-S35

Copy of the ${ }^{1} \mathrm{H}$ NMR and ${ }^{13}$ CNMR spectrum for the benzamides $6 \mathbf{b}, \mathbf{6 f}-\mathbf{i}::$ S36-S47

Copy of the ${ }^{1} \mathrm{H}$ NMR and ${ }^{13}$ CNMR spectrum for the benzamides $\mathbf{7 b}, \mathbf{7 f}-\mathbf{h}$ : S48-S55

Copy of the ${ }^{1} \mathrm{H}$ NMR and ${ }^{13}$ CNMR spectrum for amine 8: S56-S57 

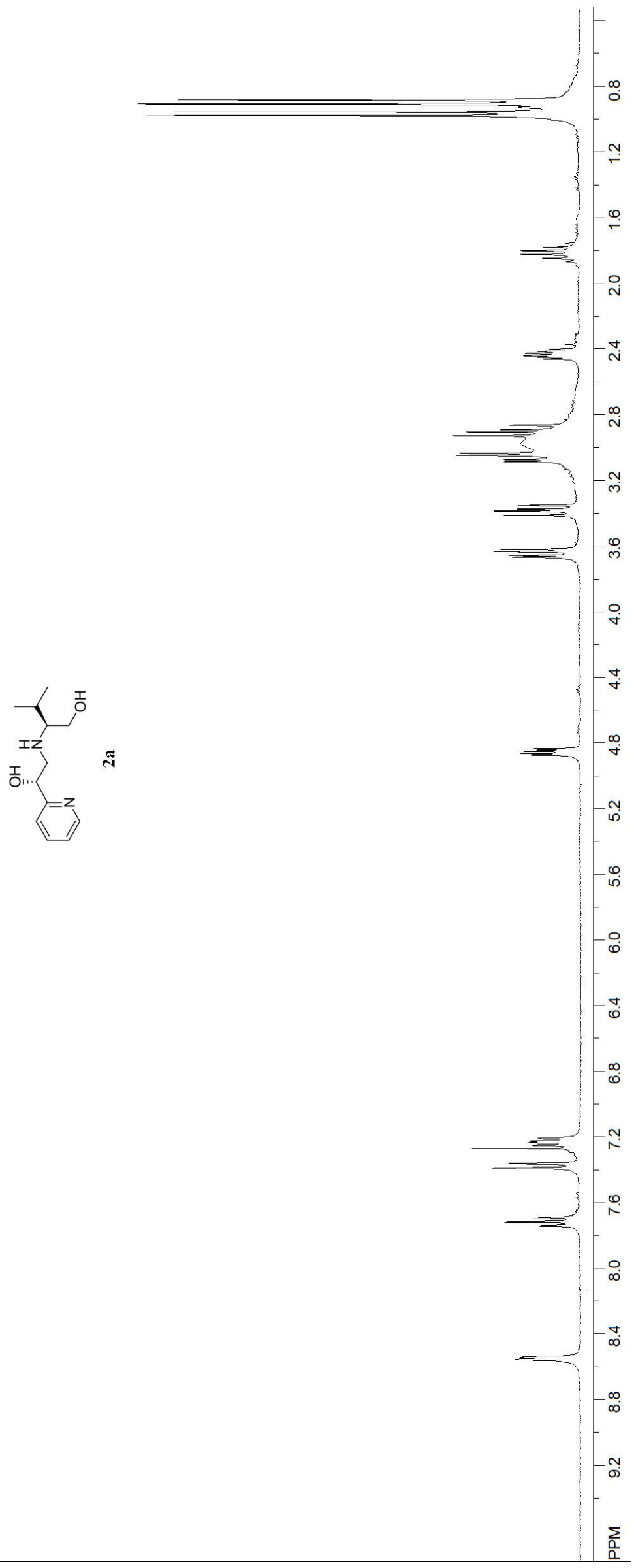


$$
1
$$




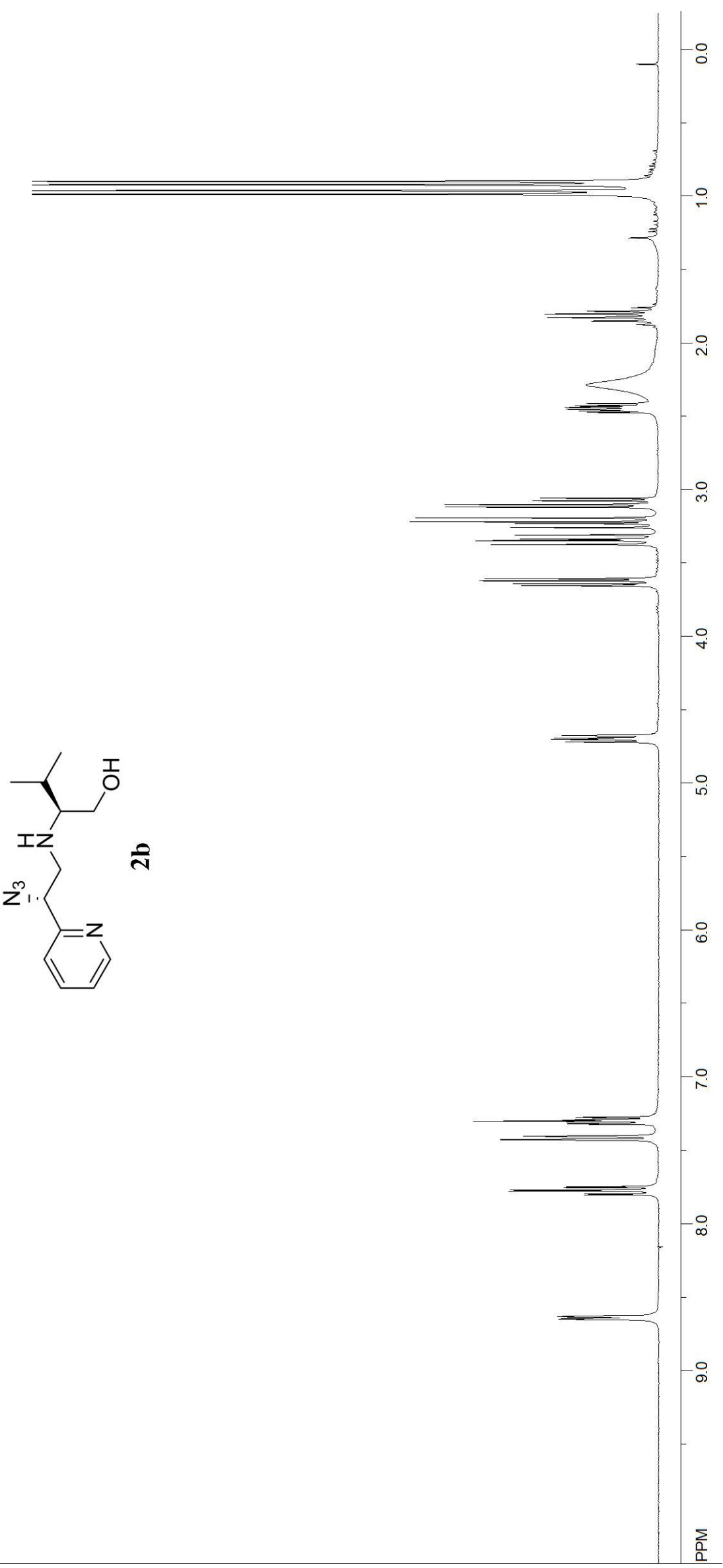




$$
1
$$




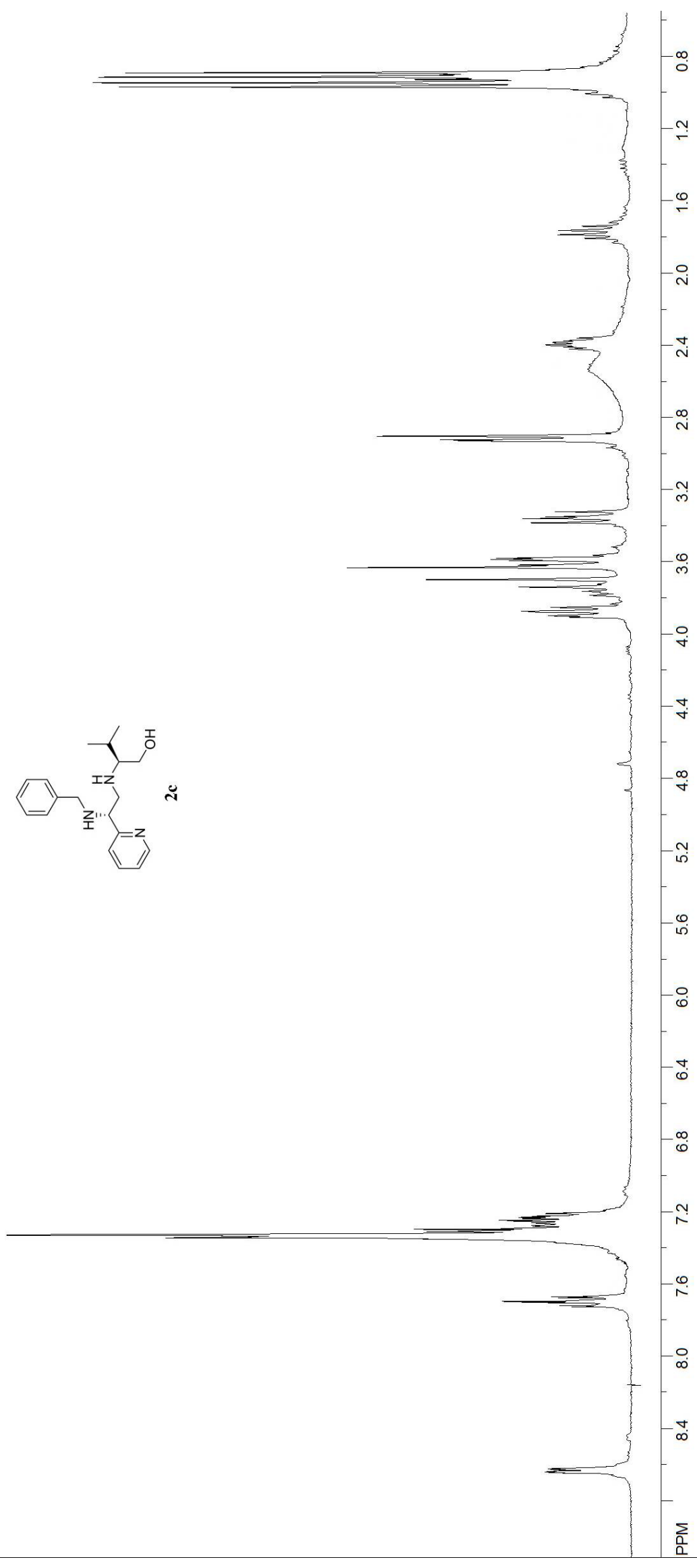




$$
1
$$




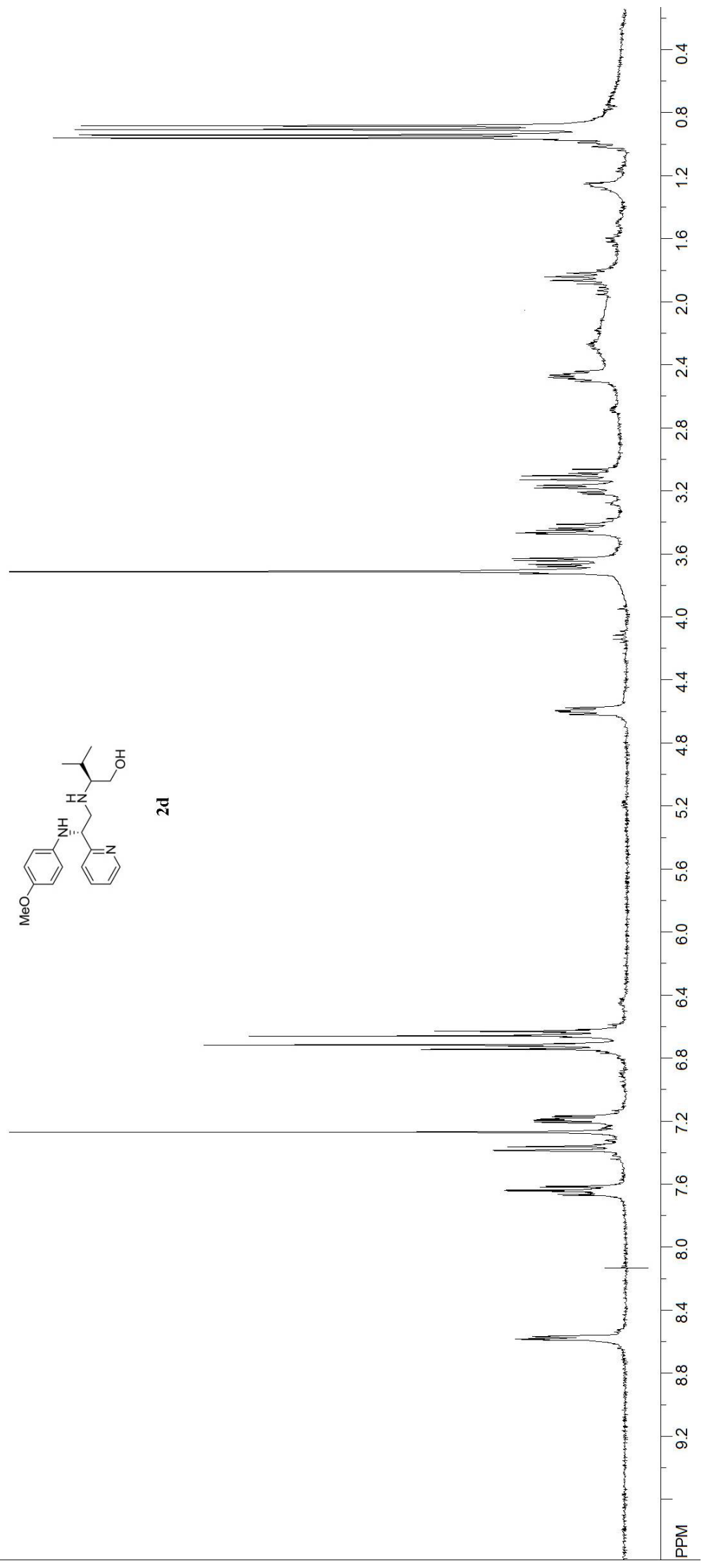




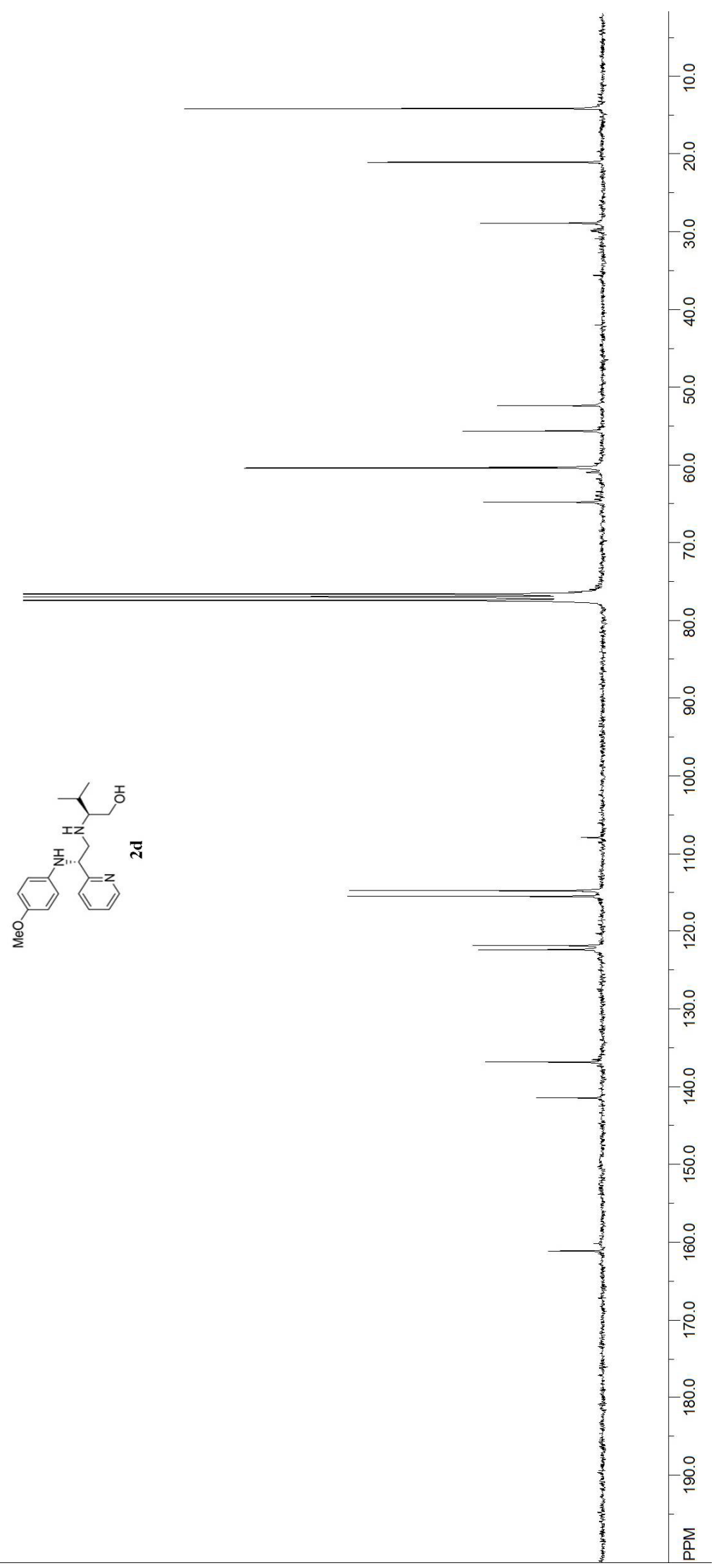




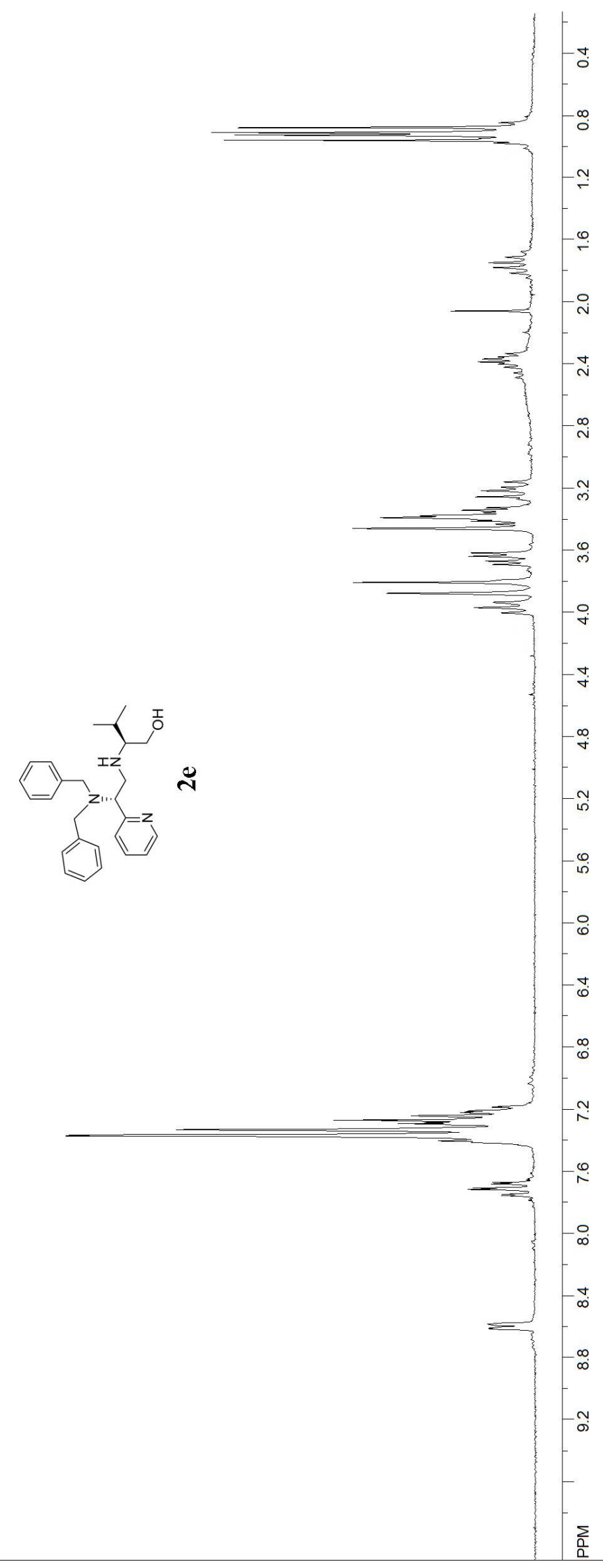




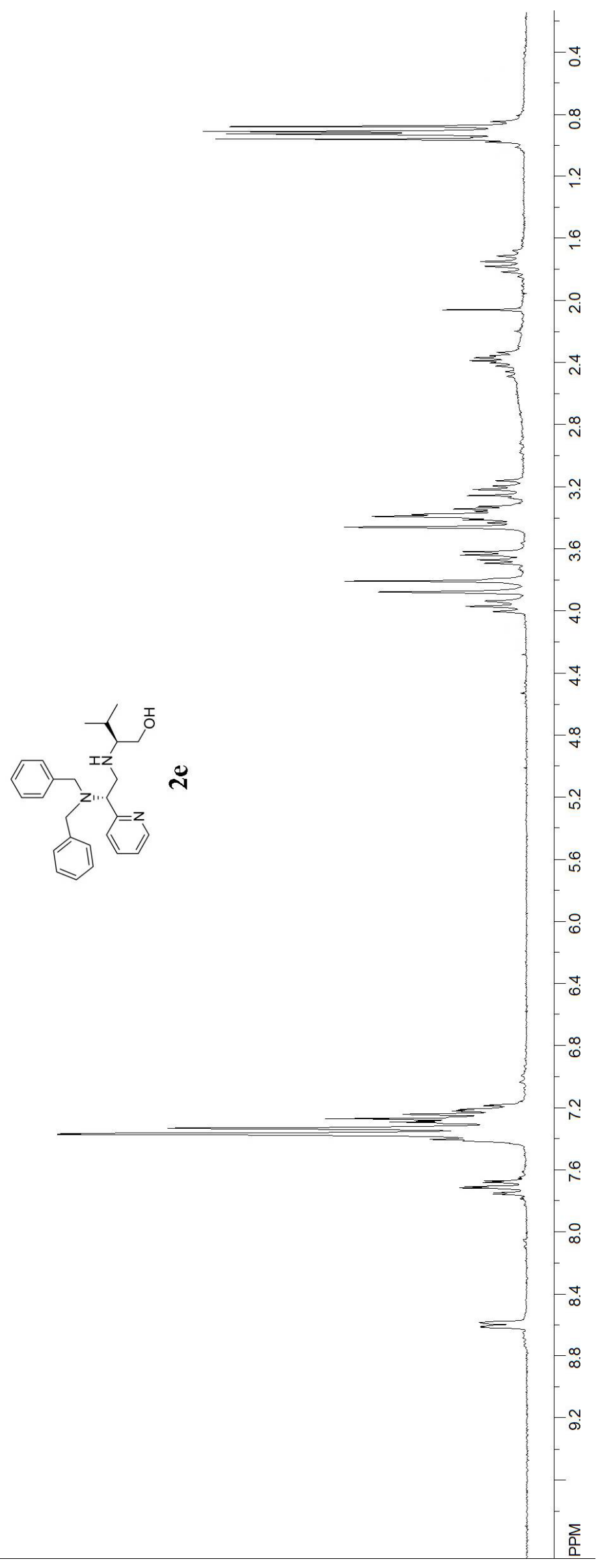




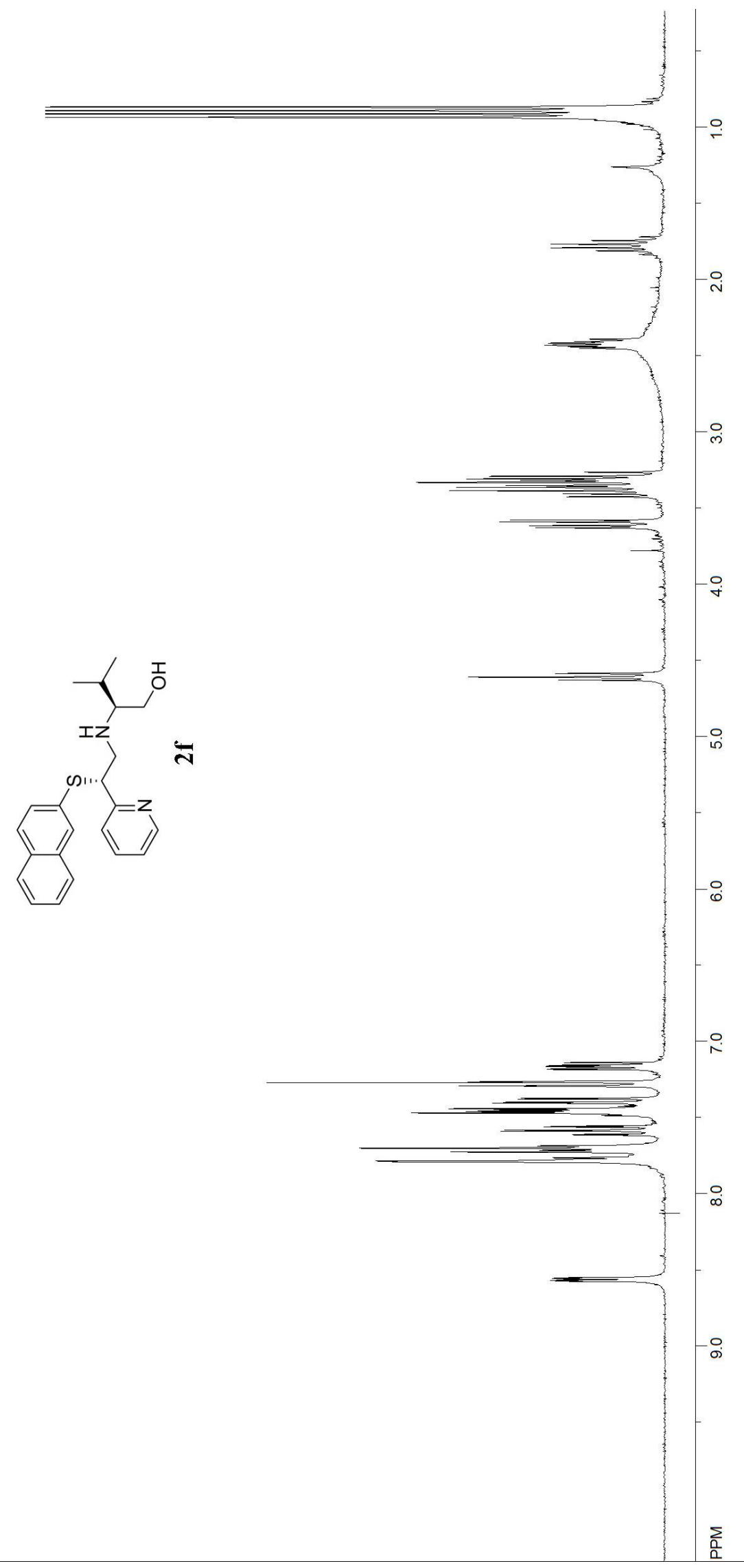




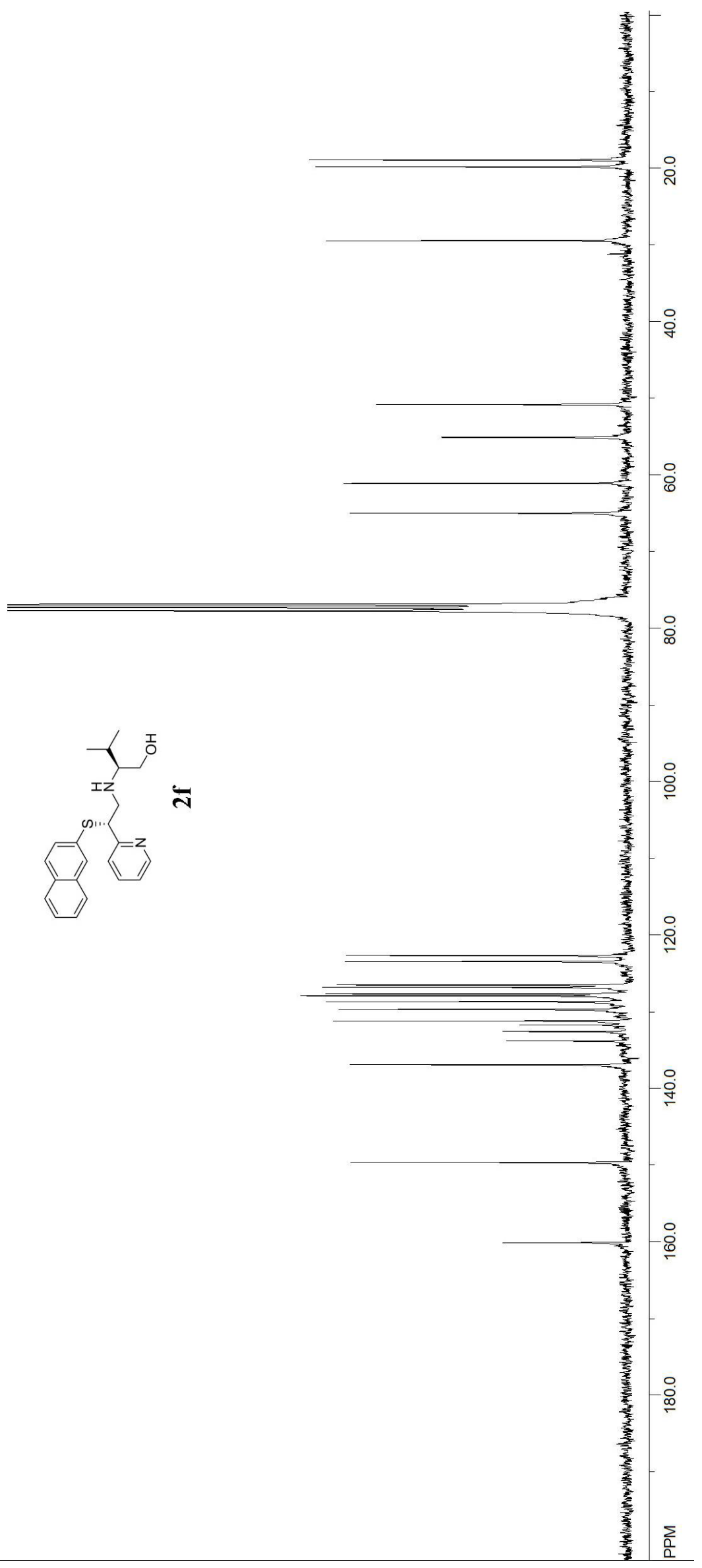




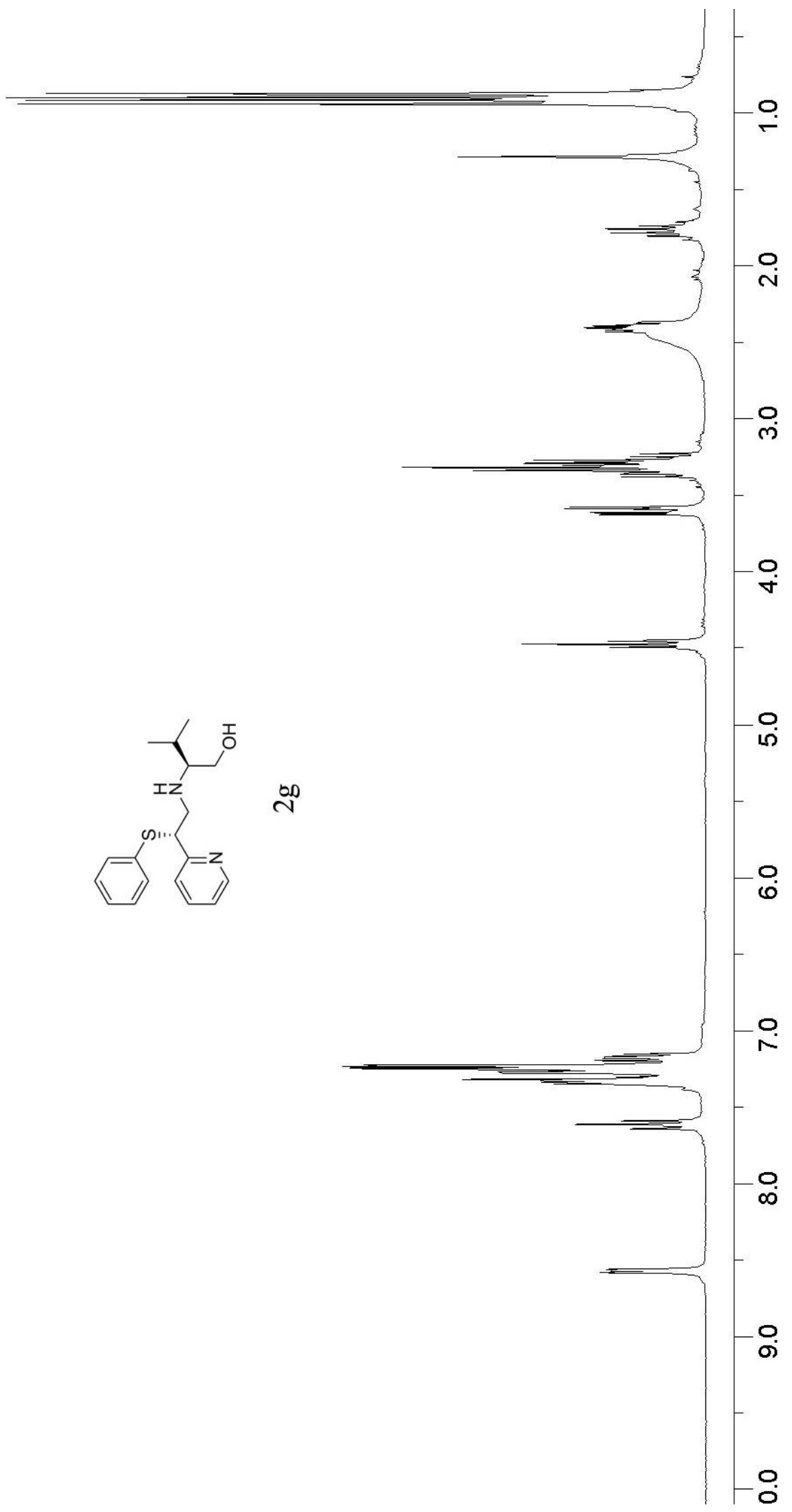




$$
1
$$




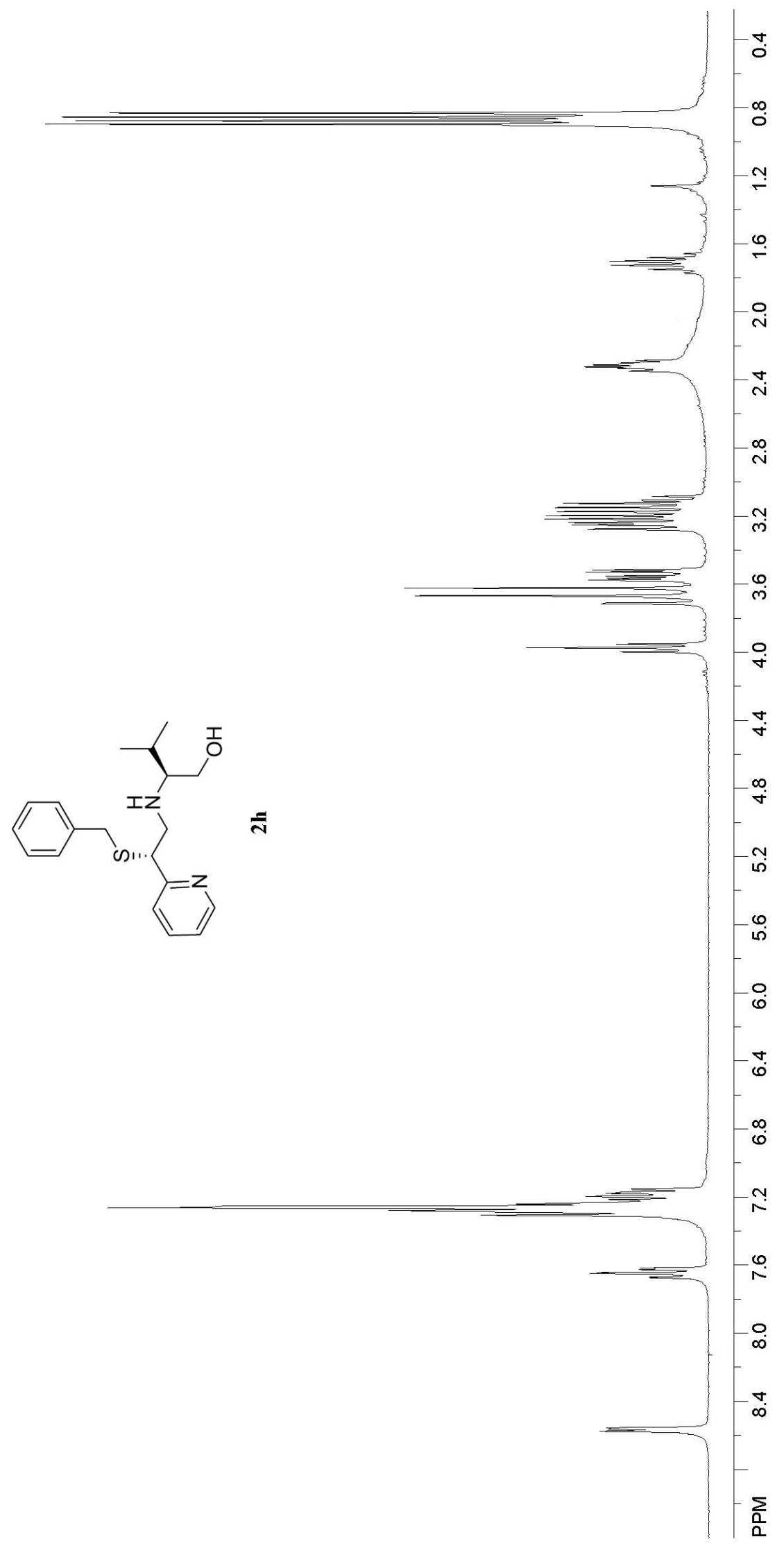




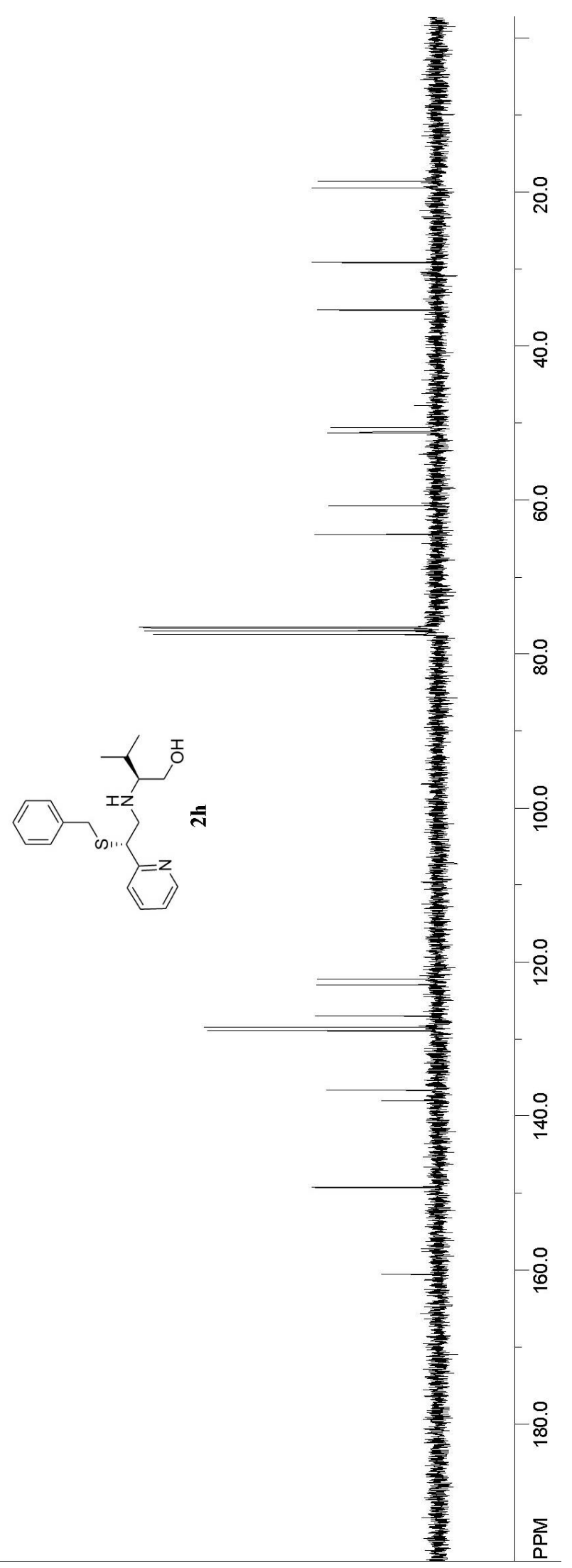




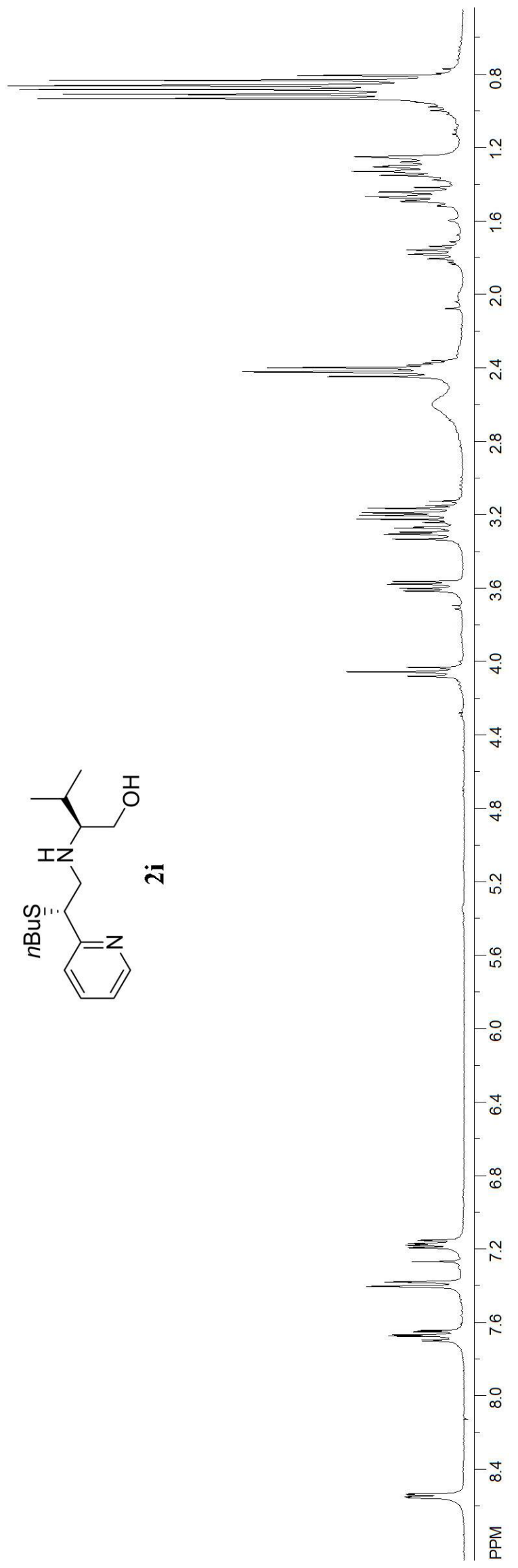




$$
1
$$




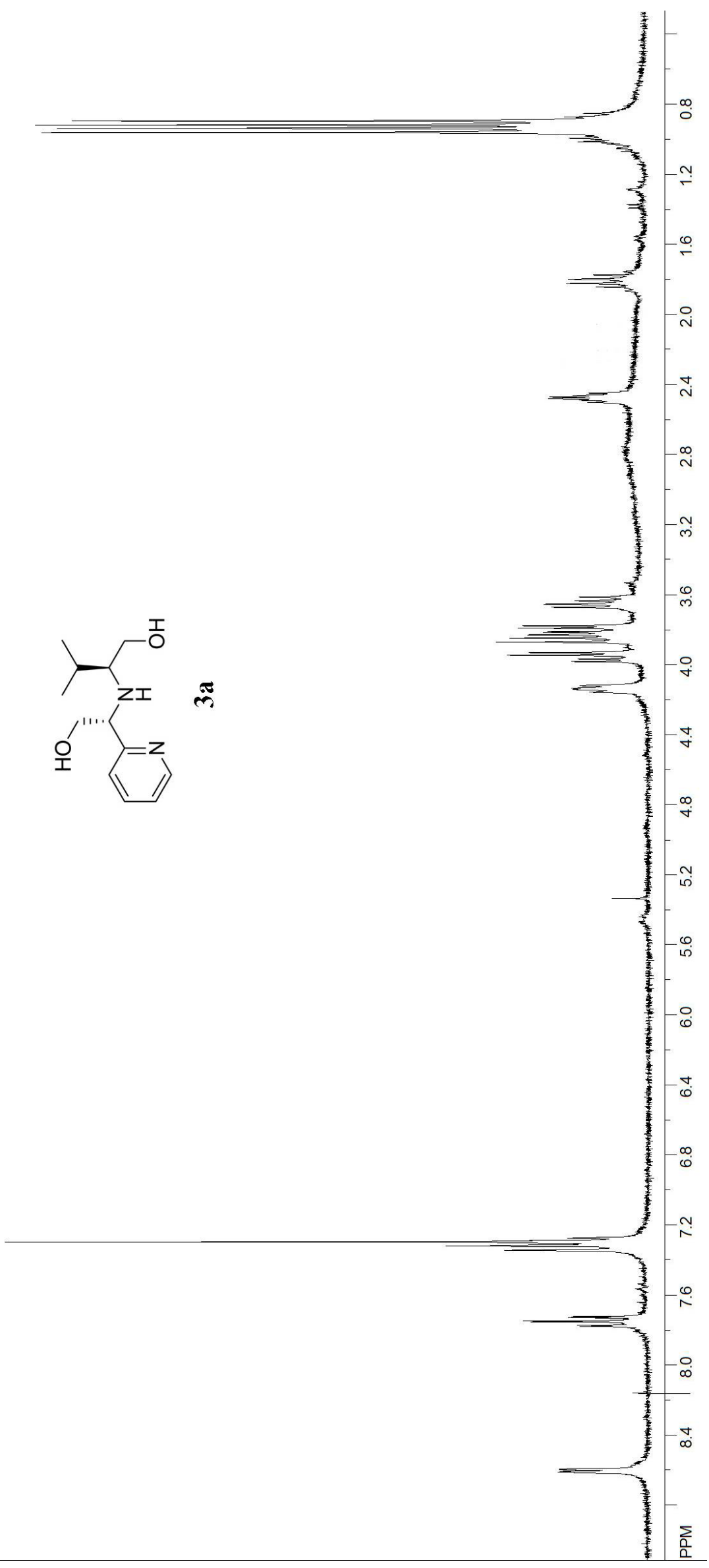




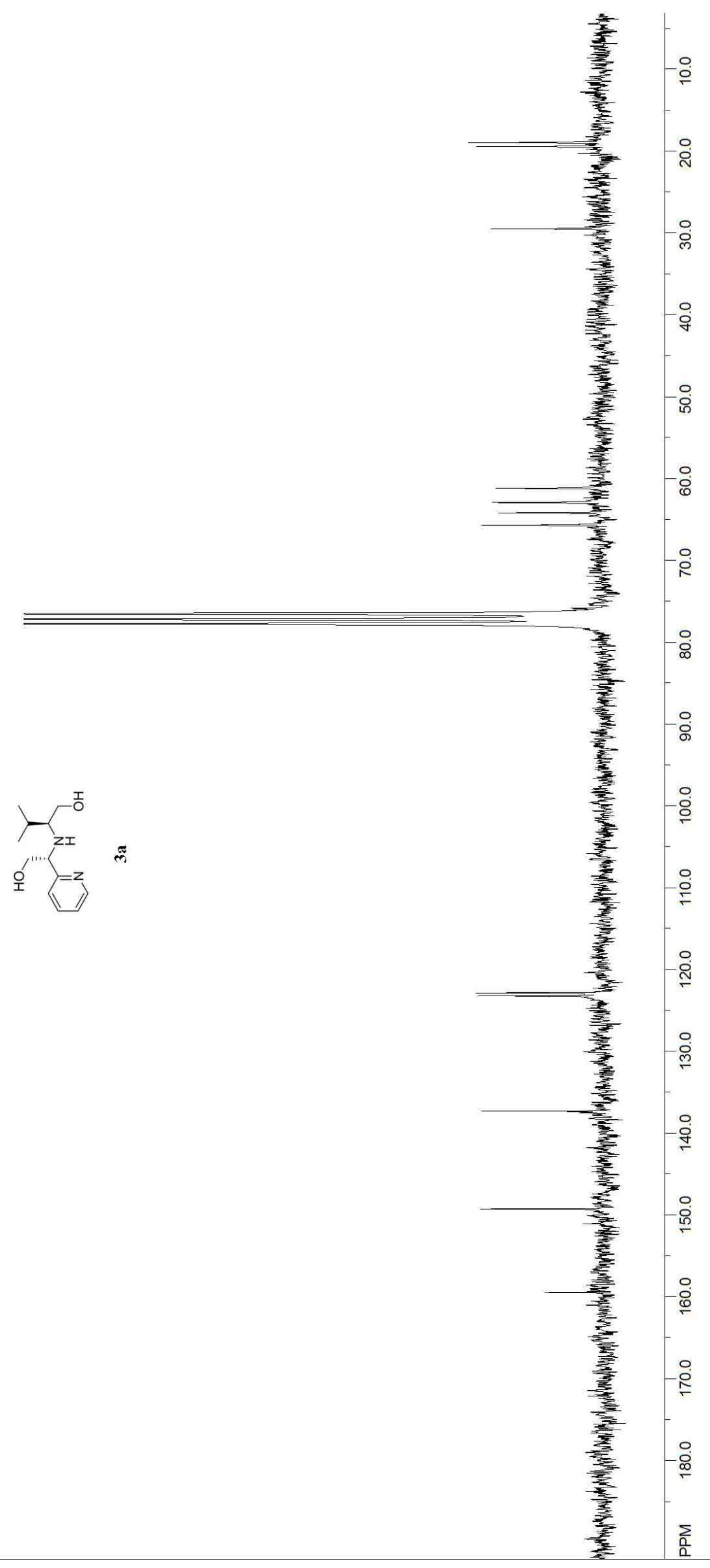




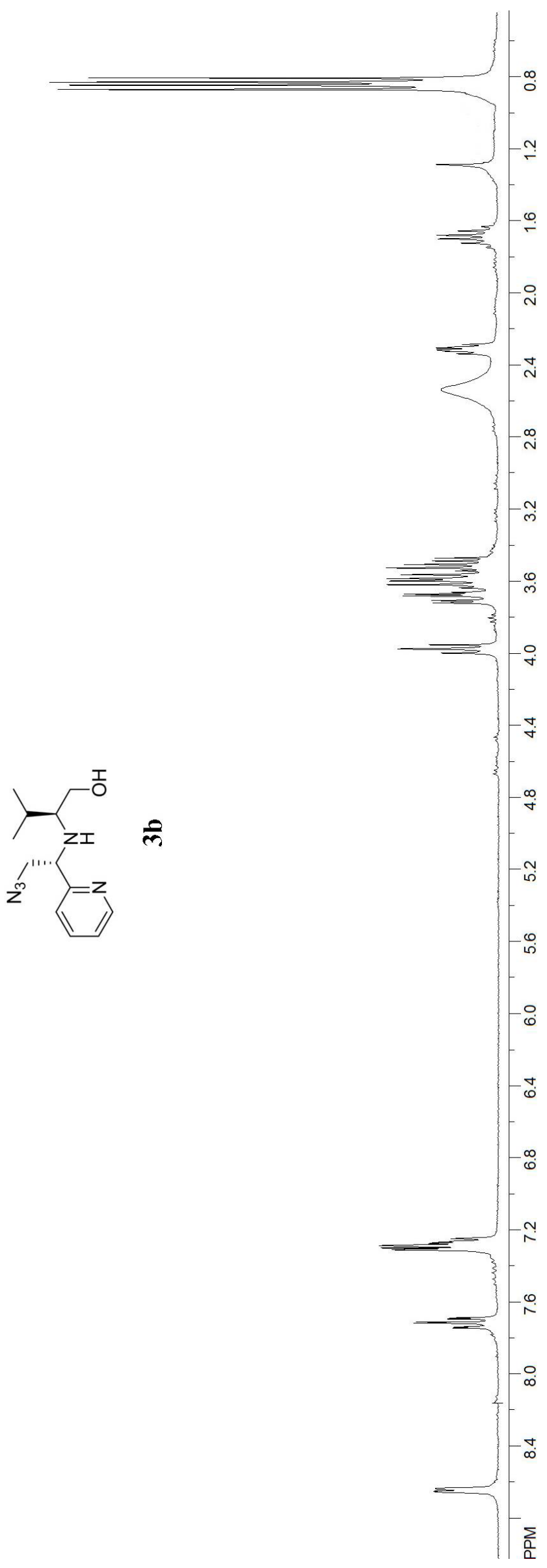




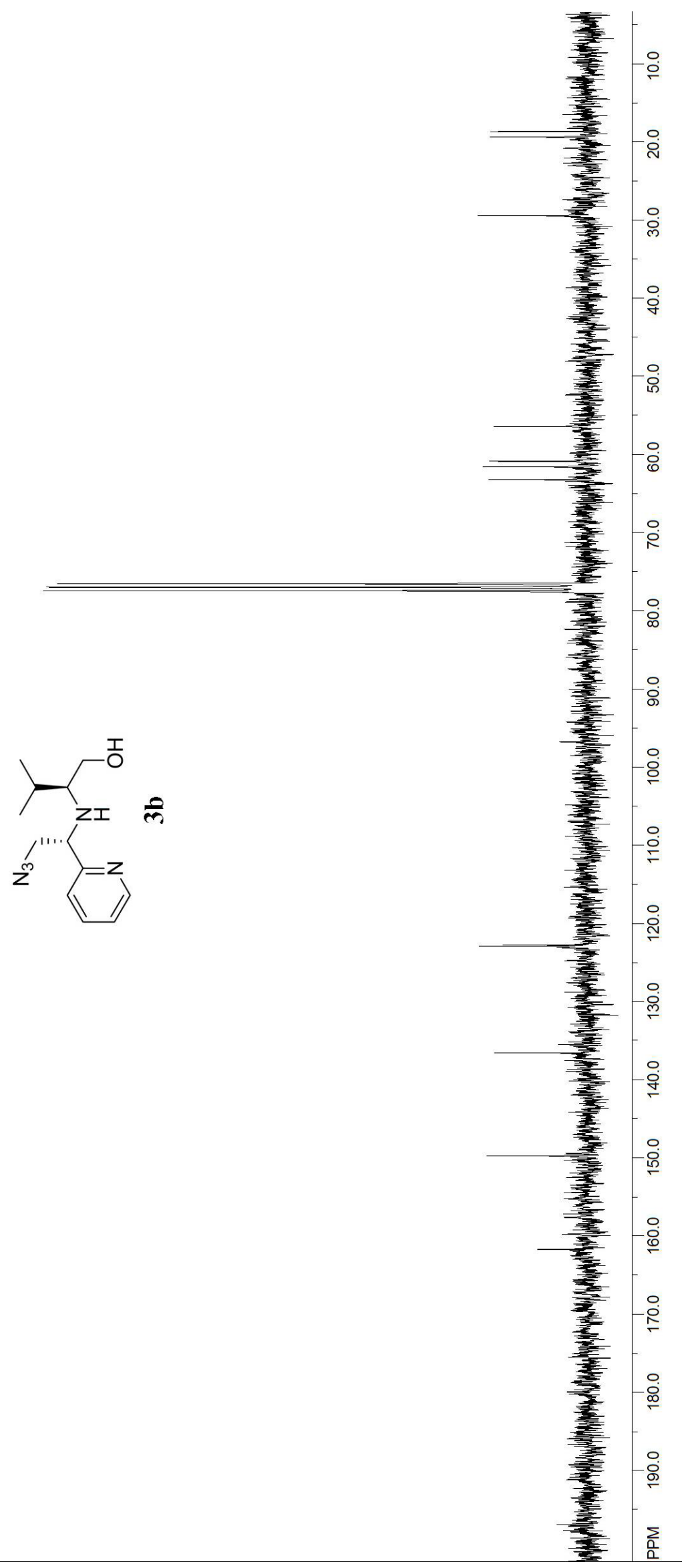




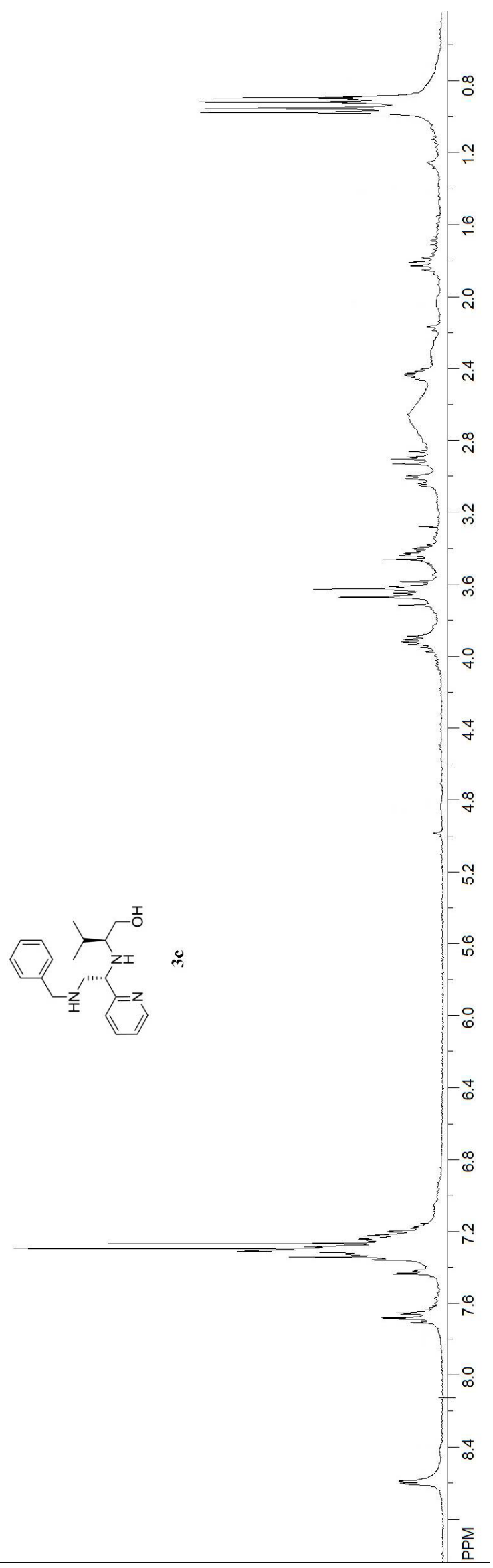




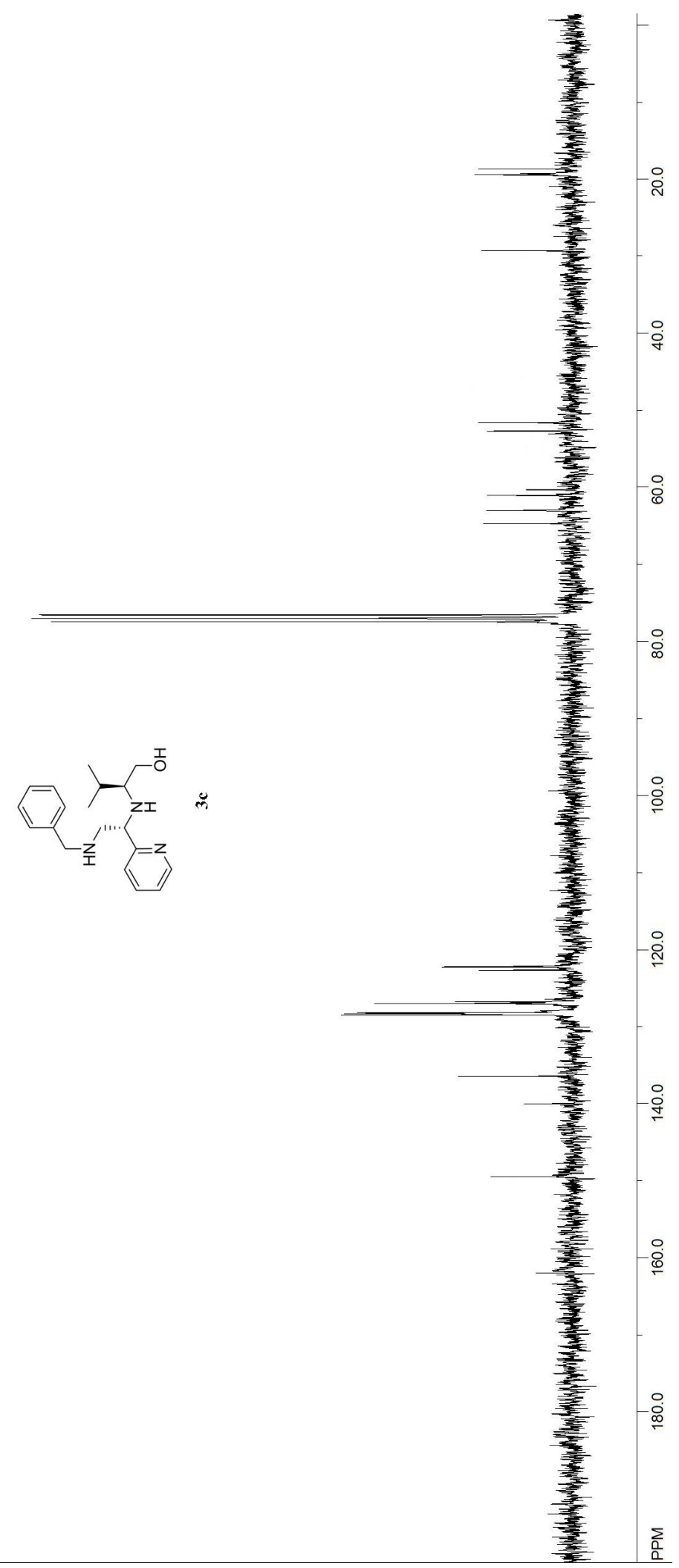




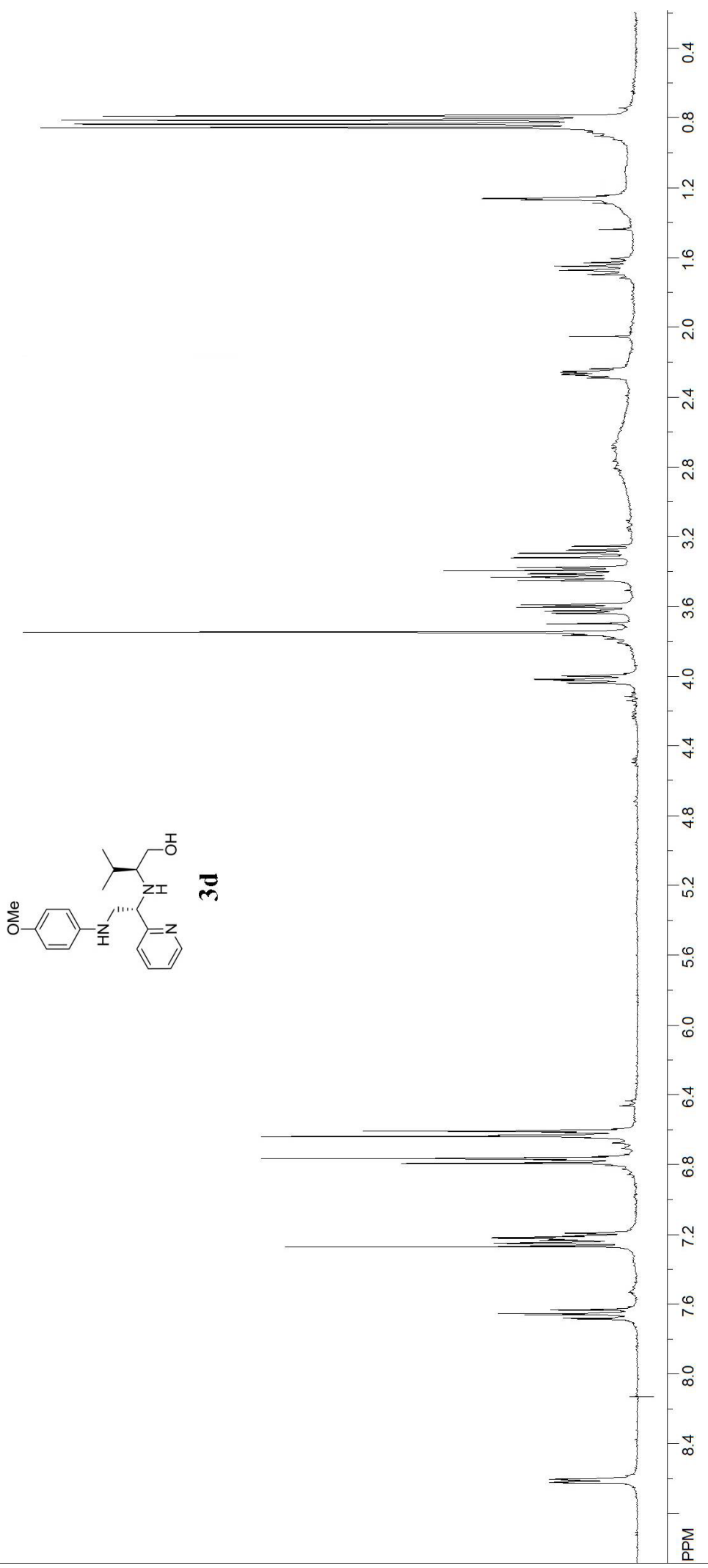




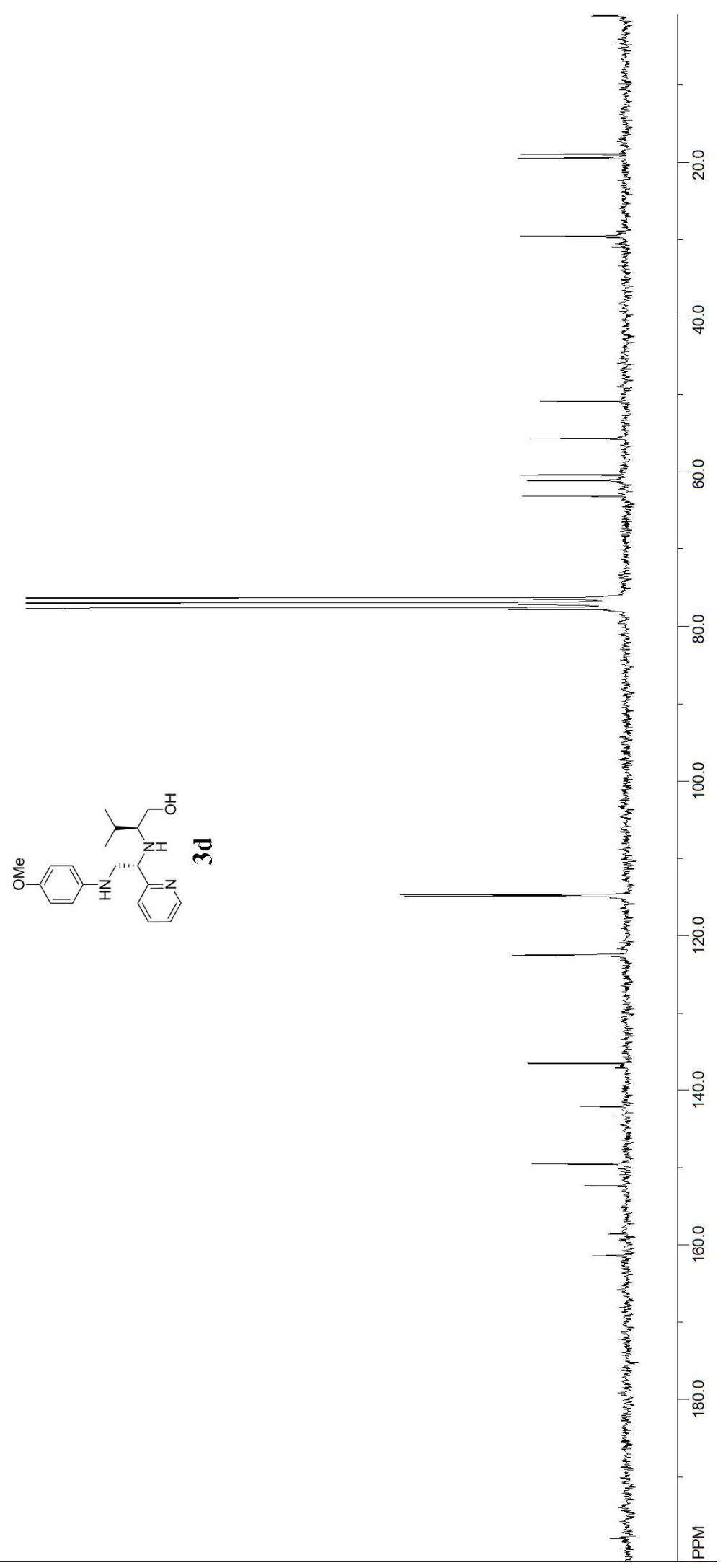



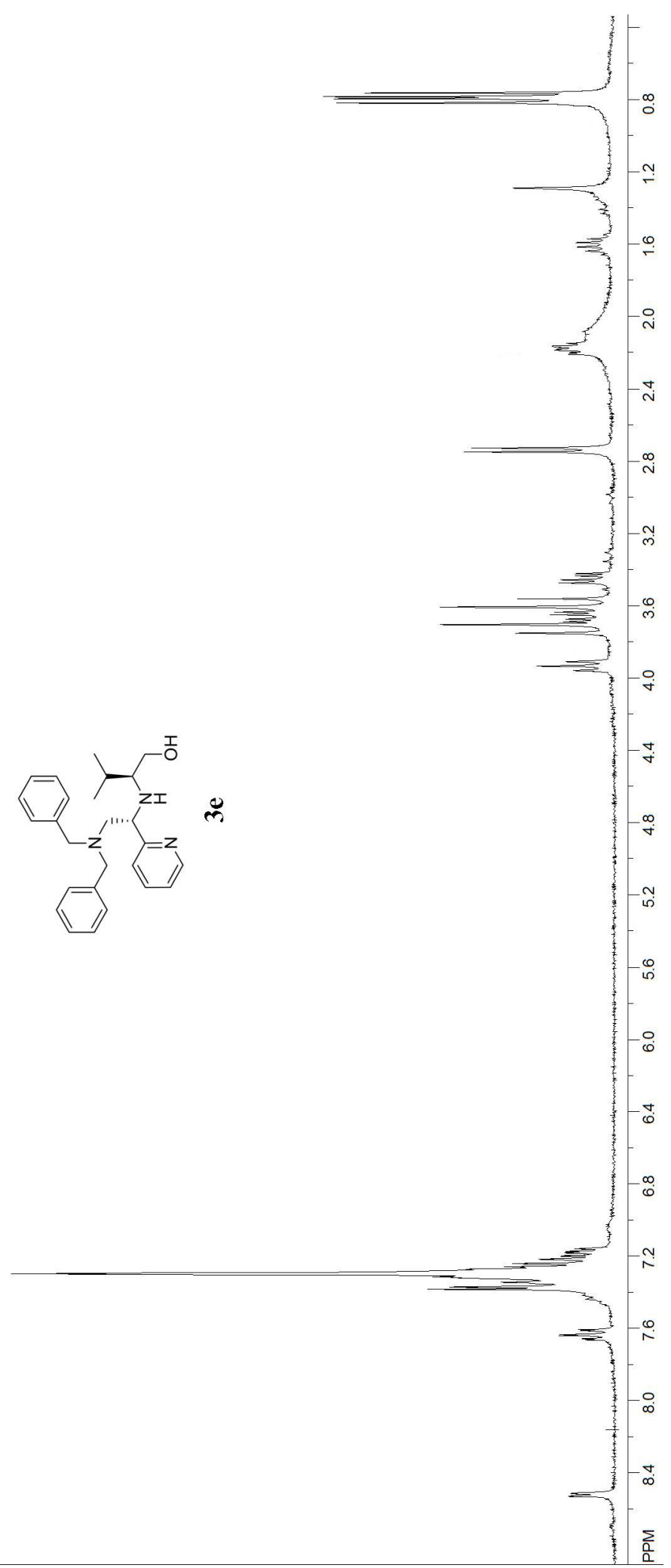


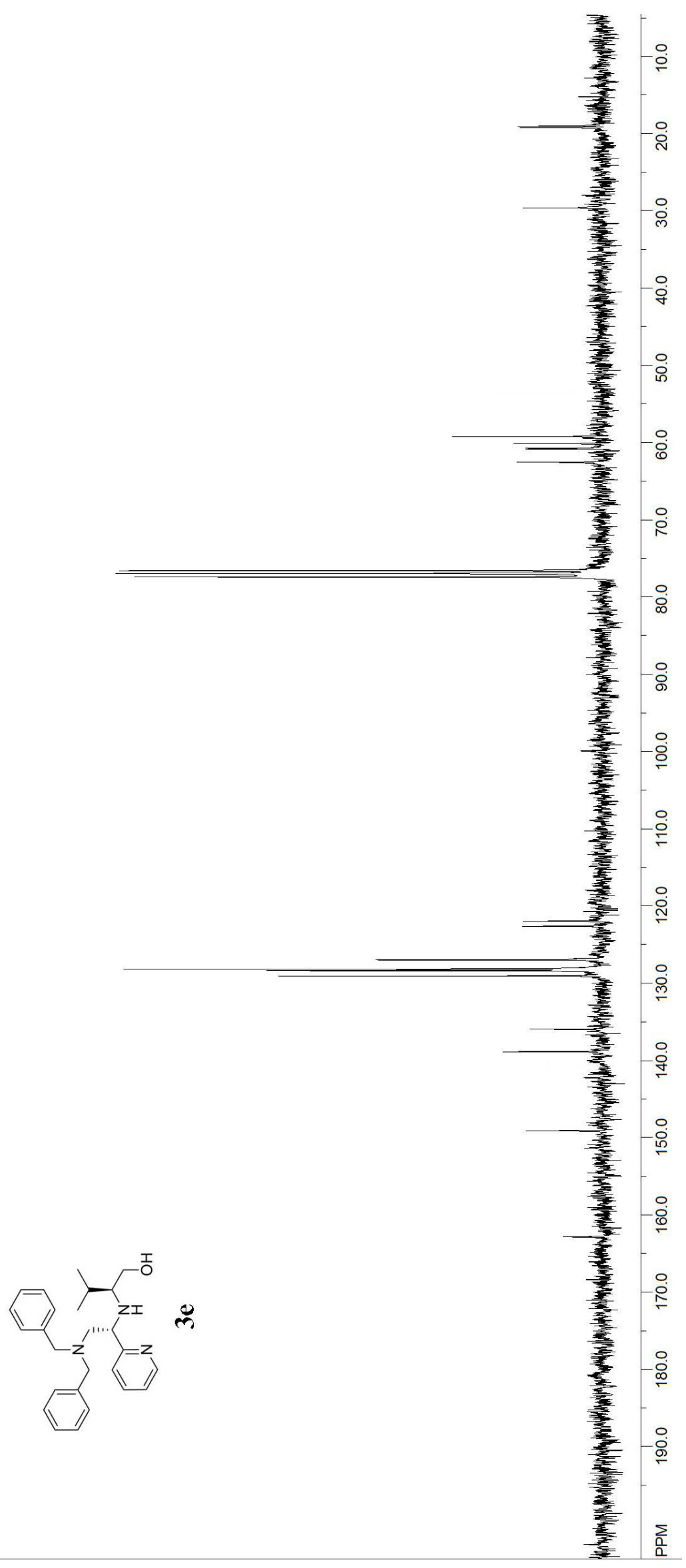




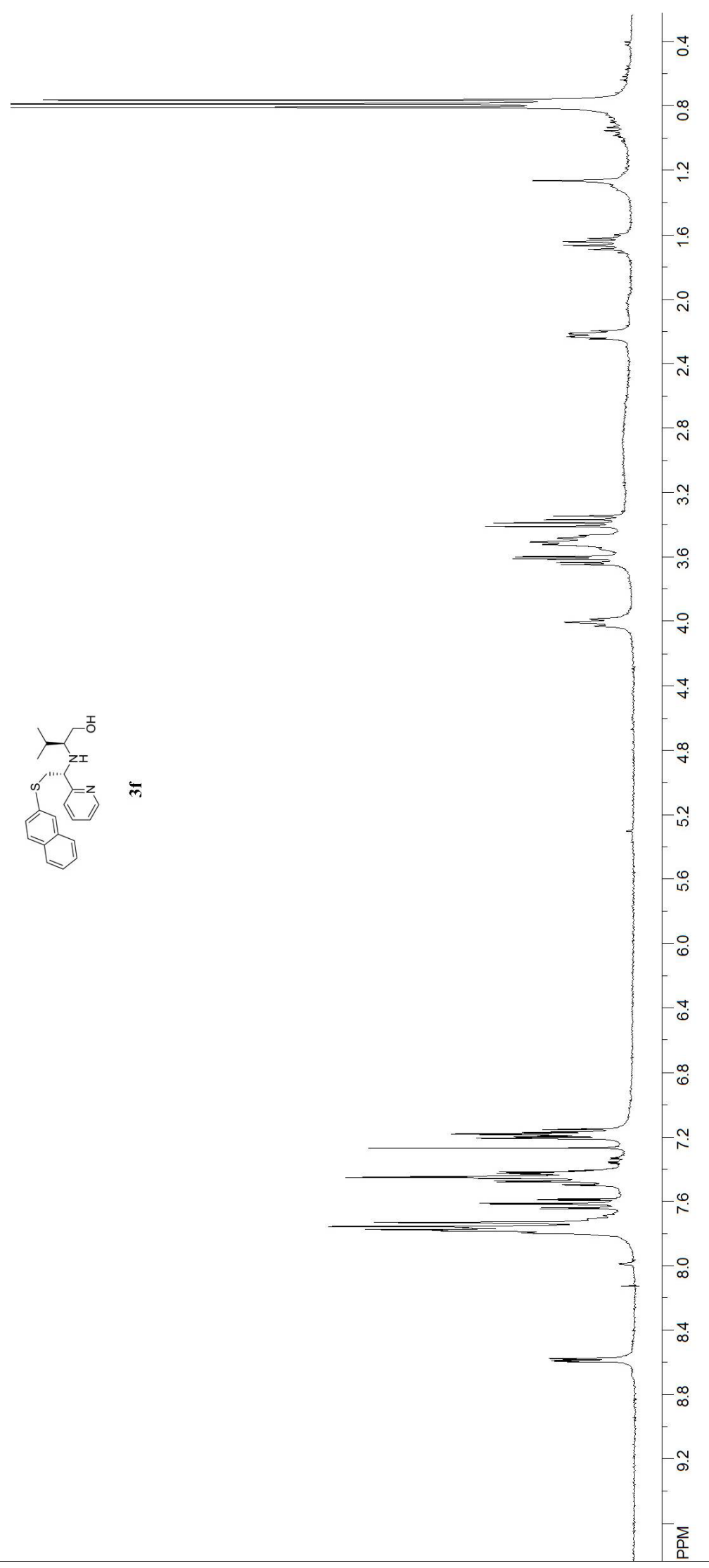




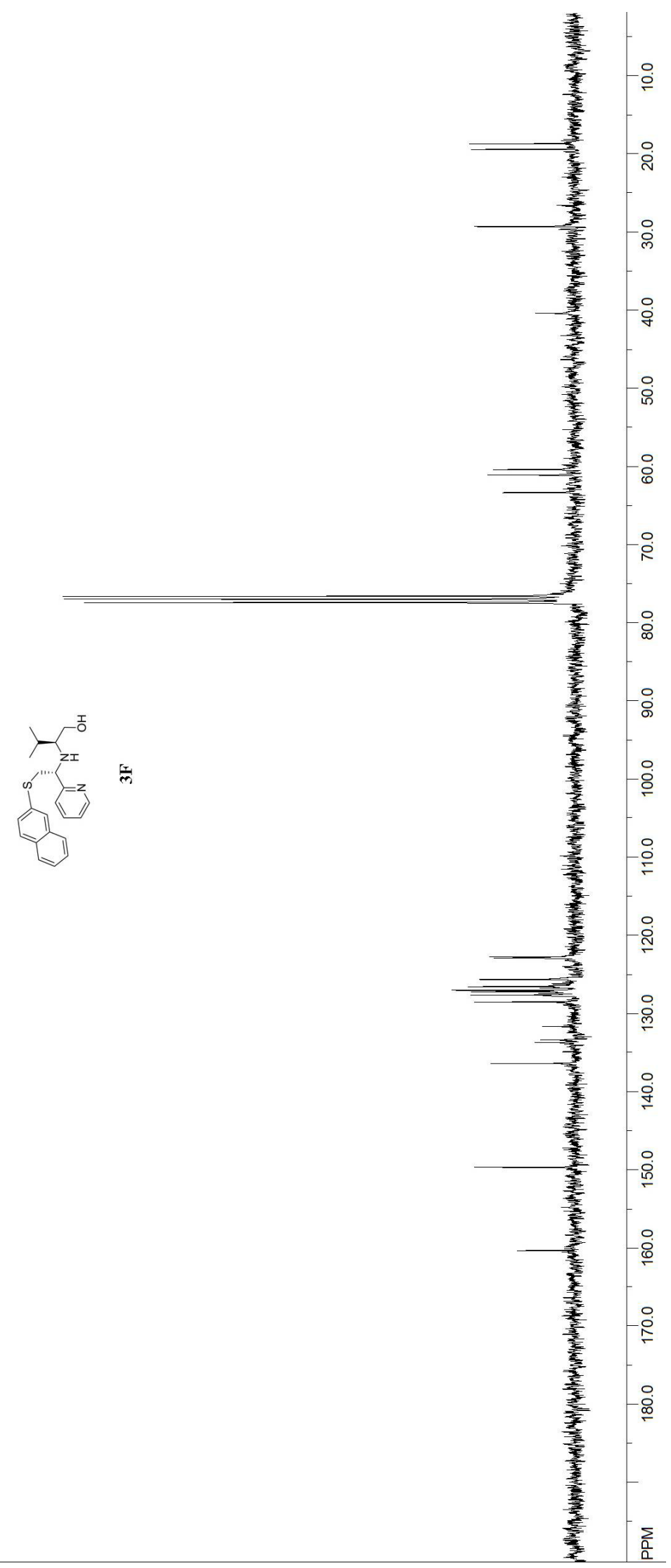




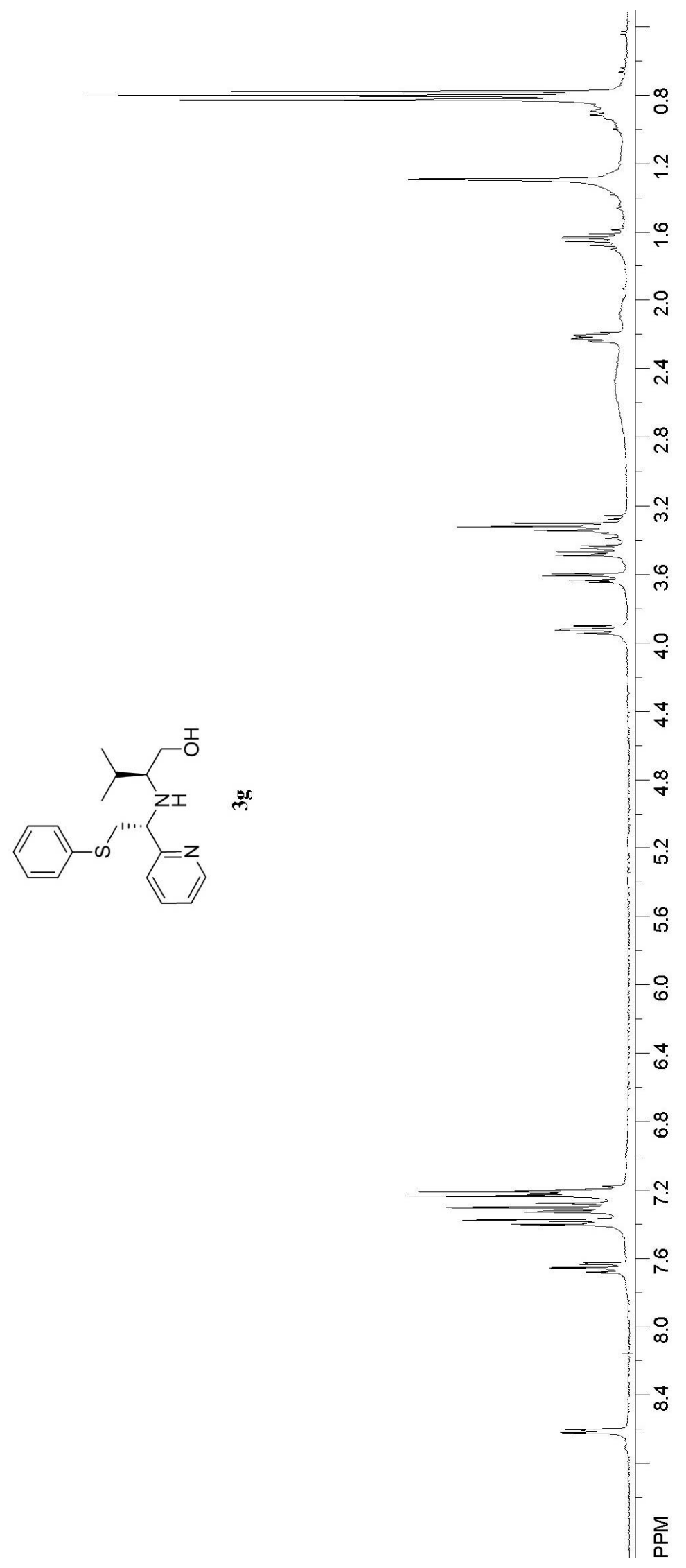




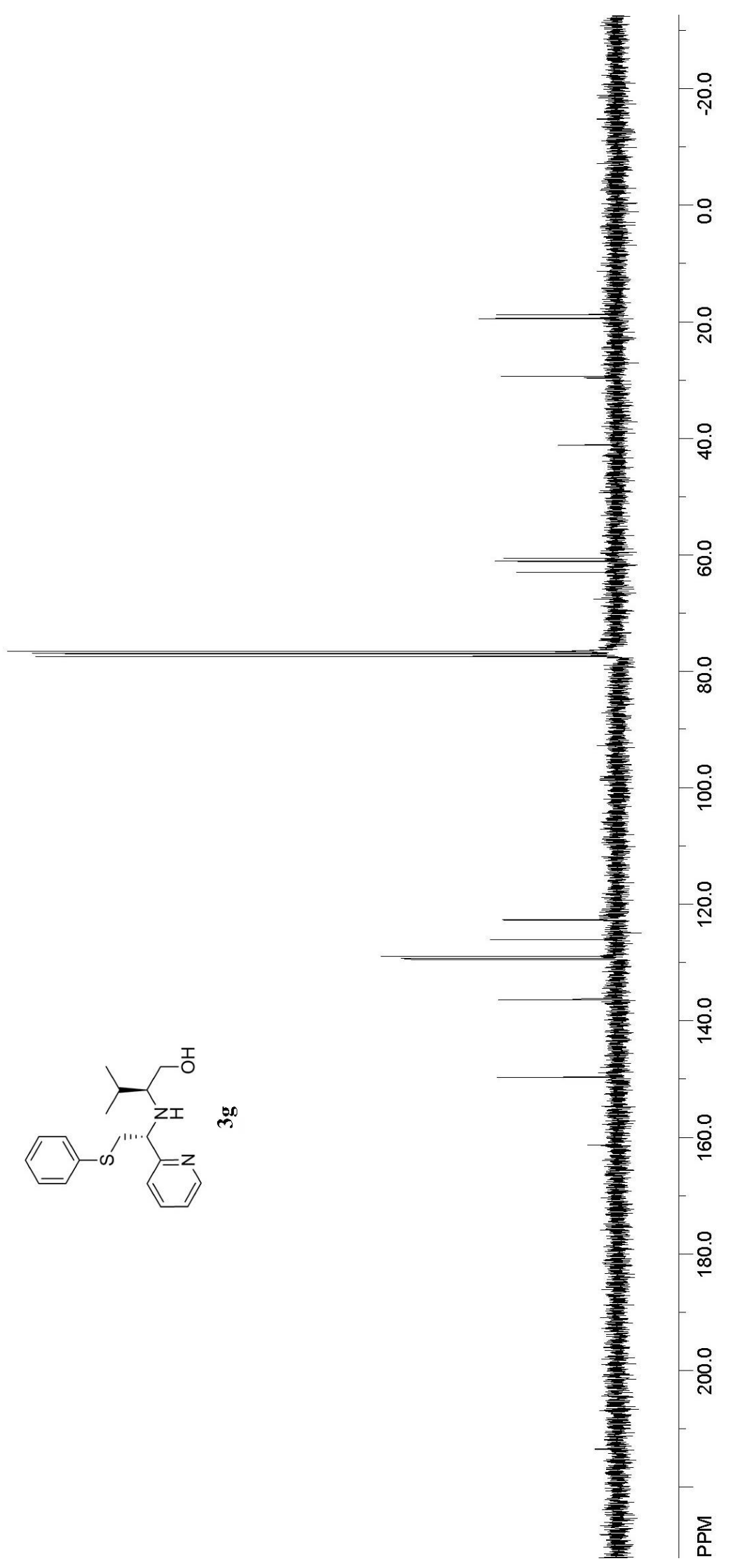




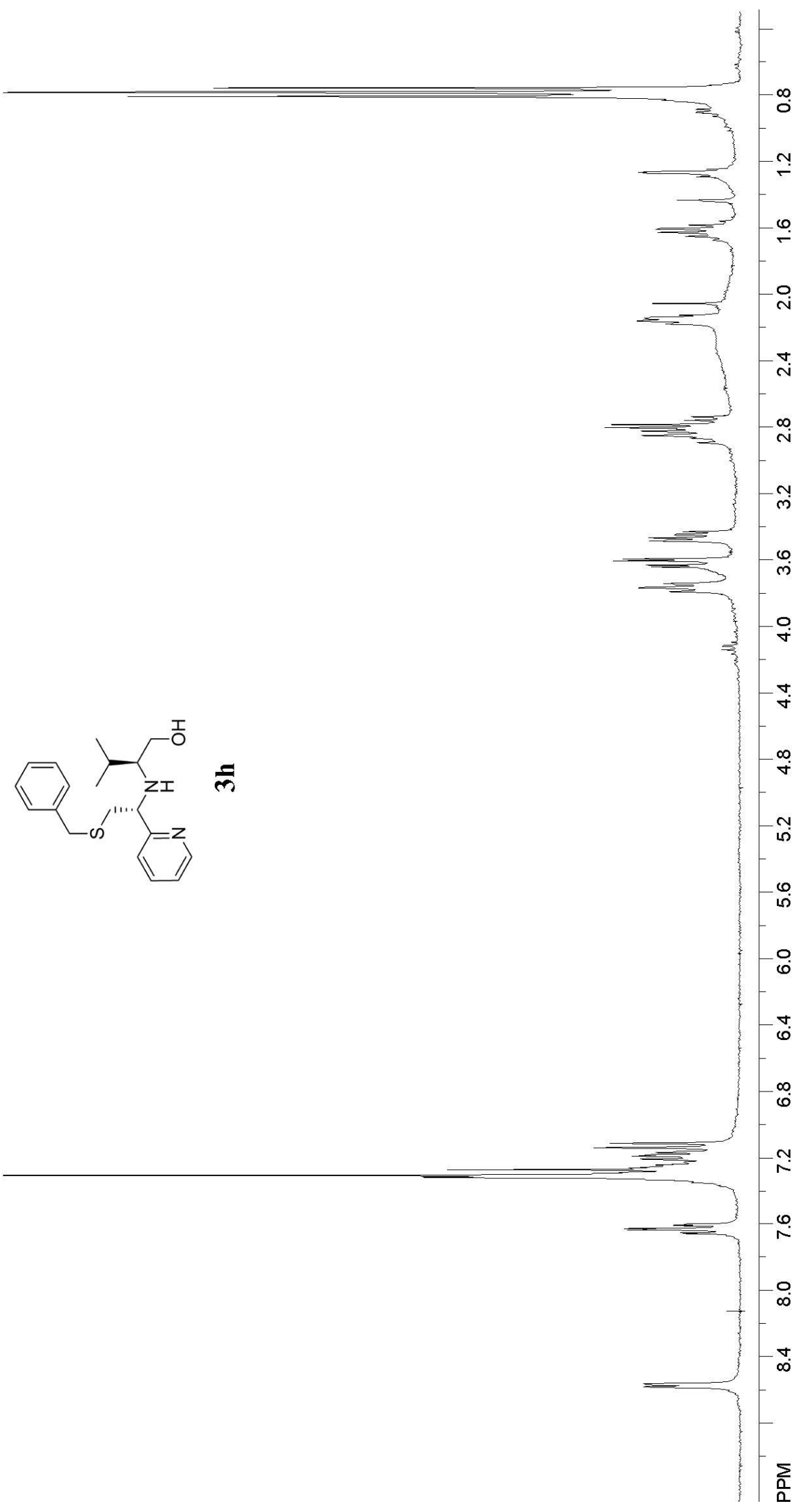




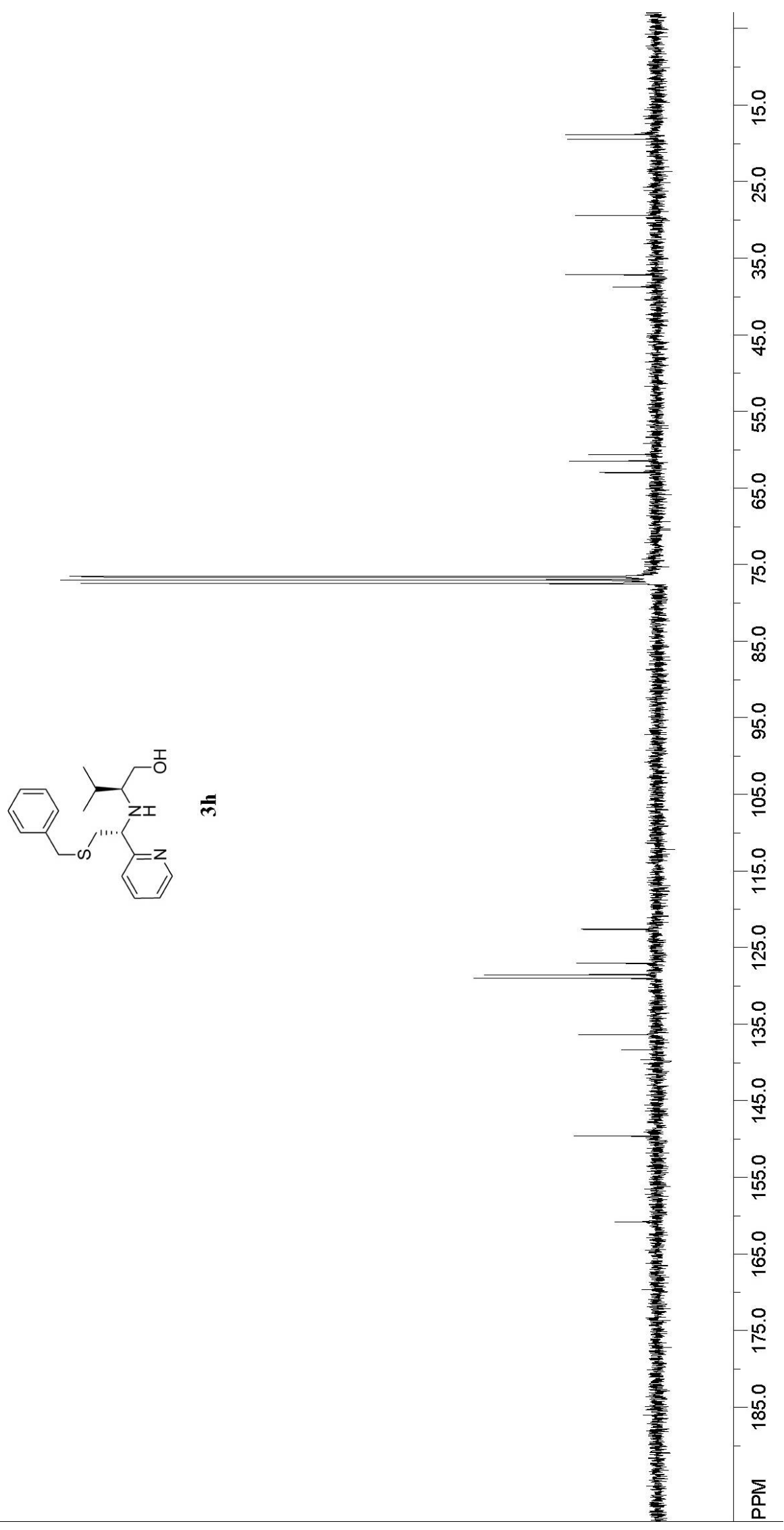




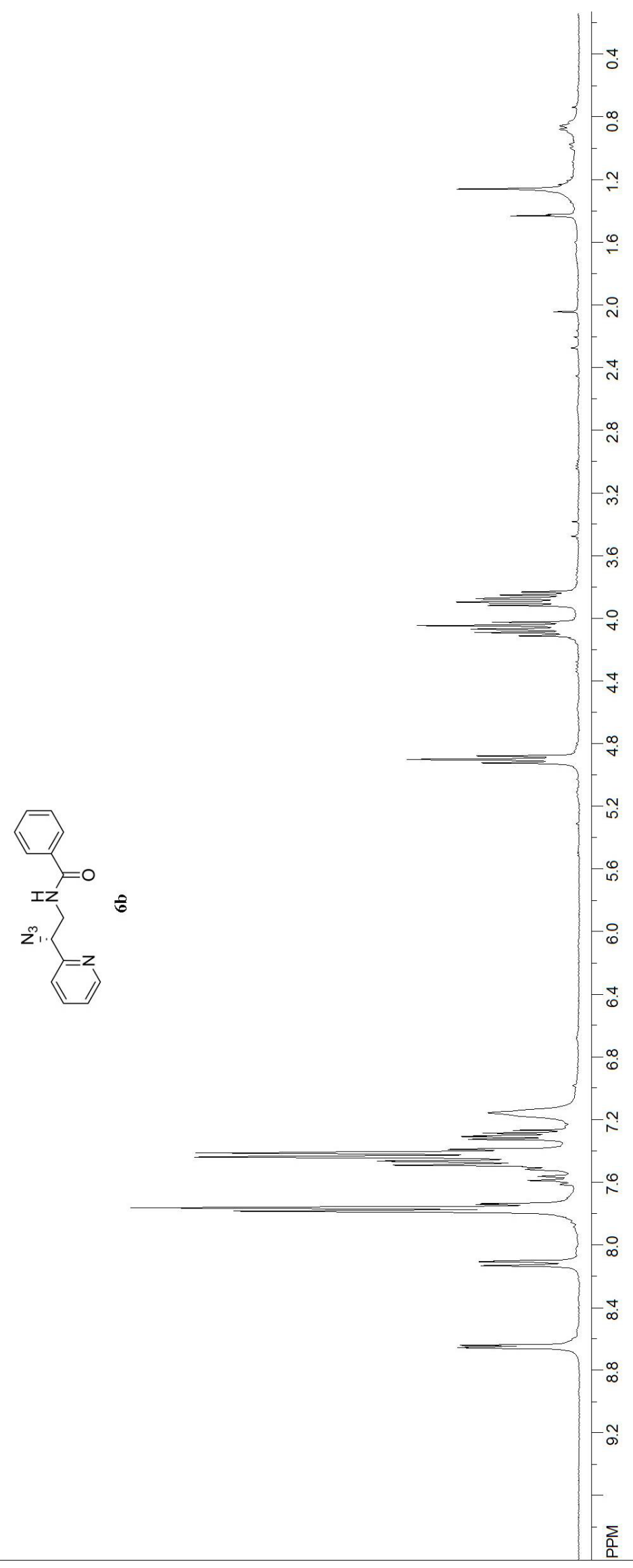




$$
1
$$




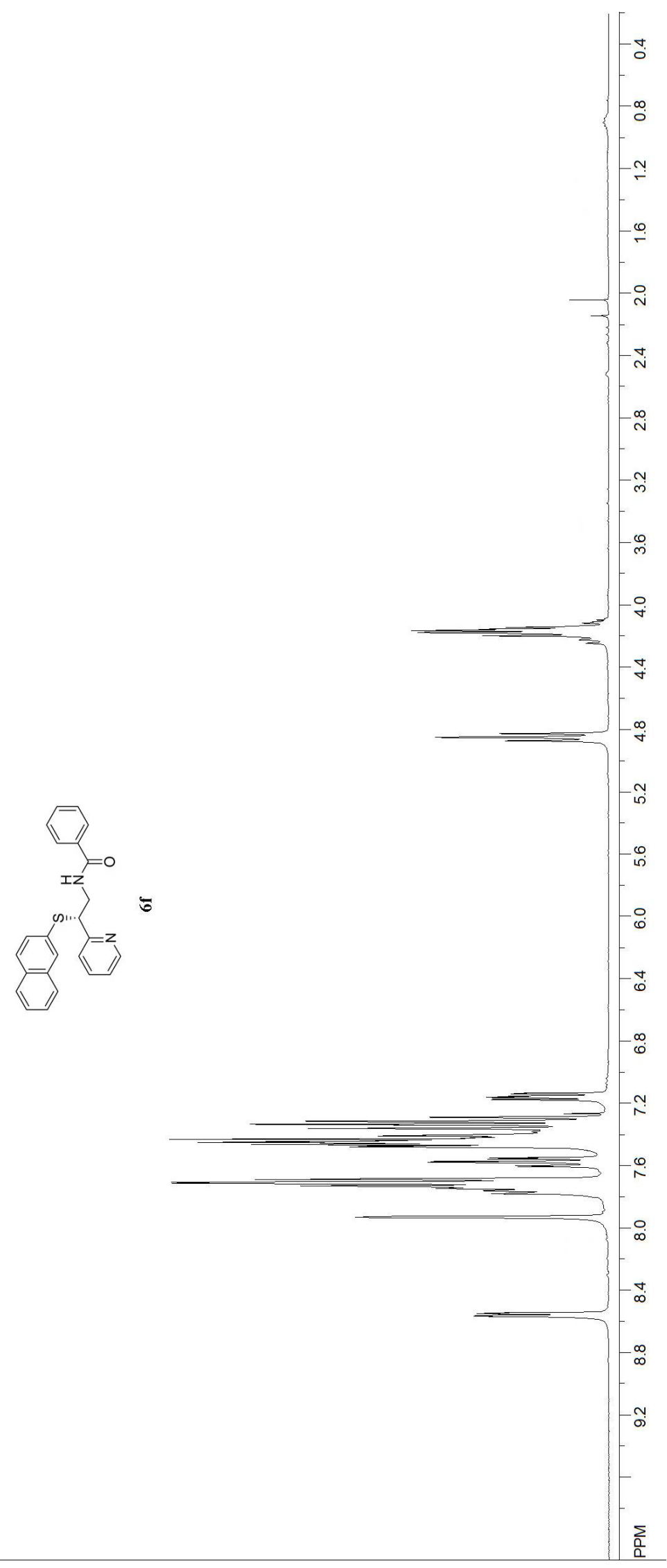




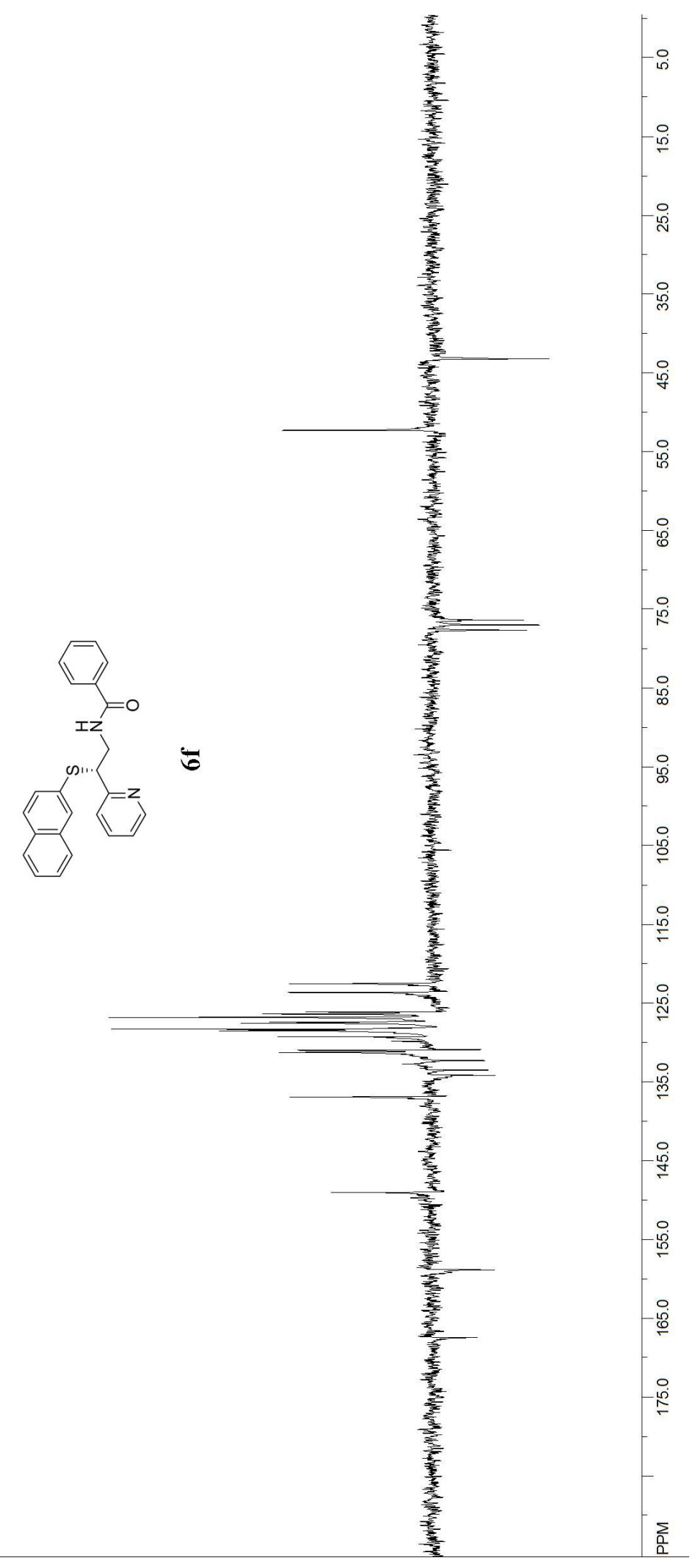




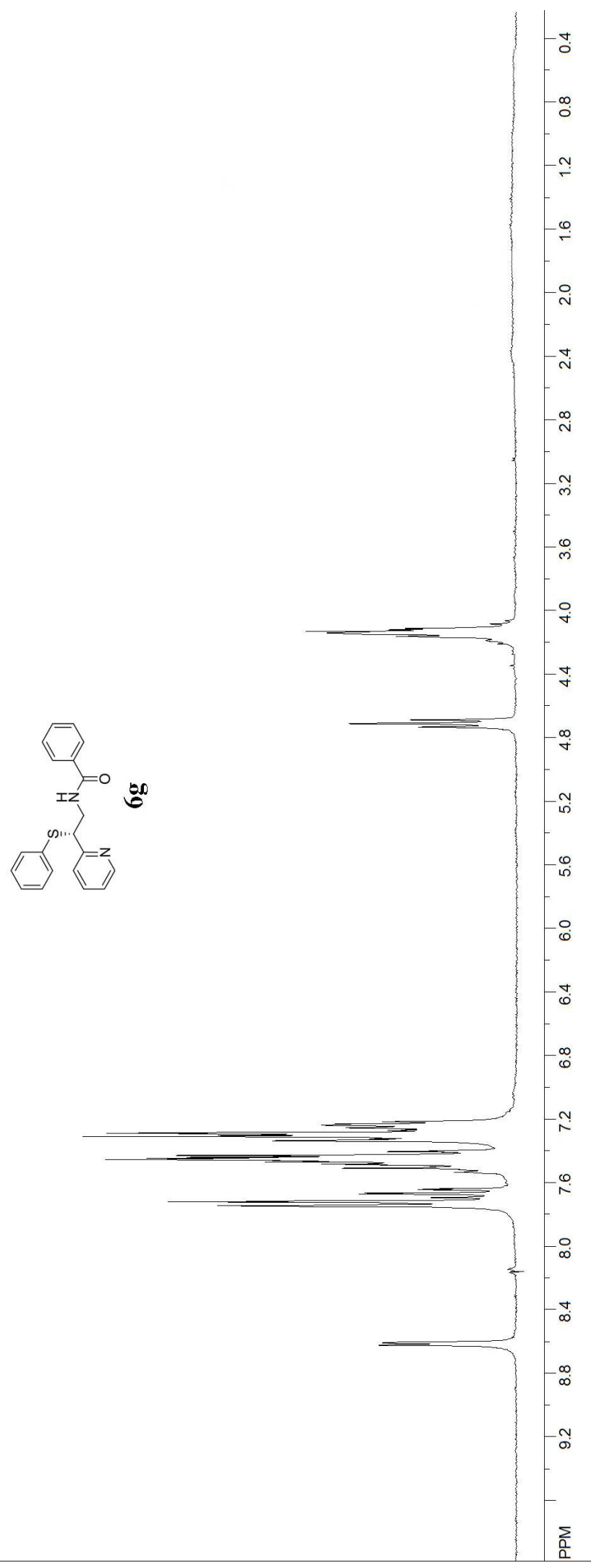




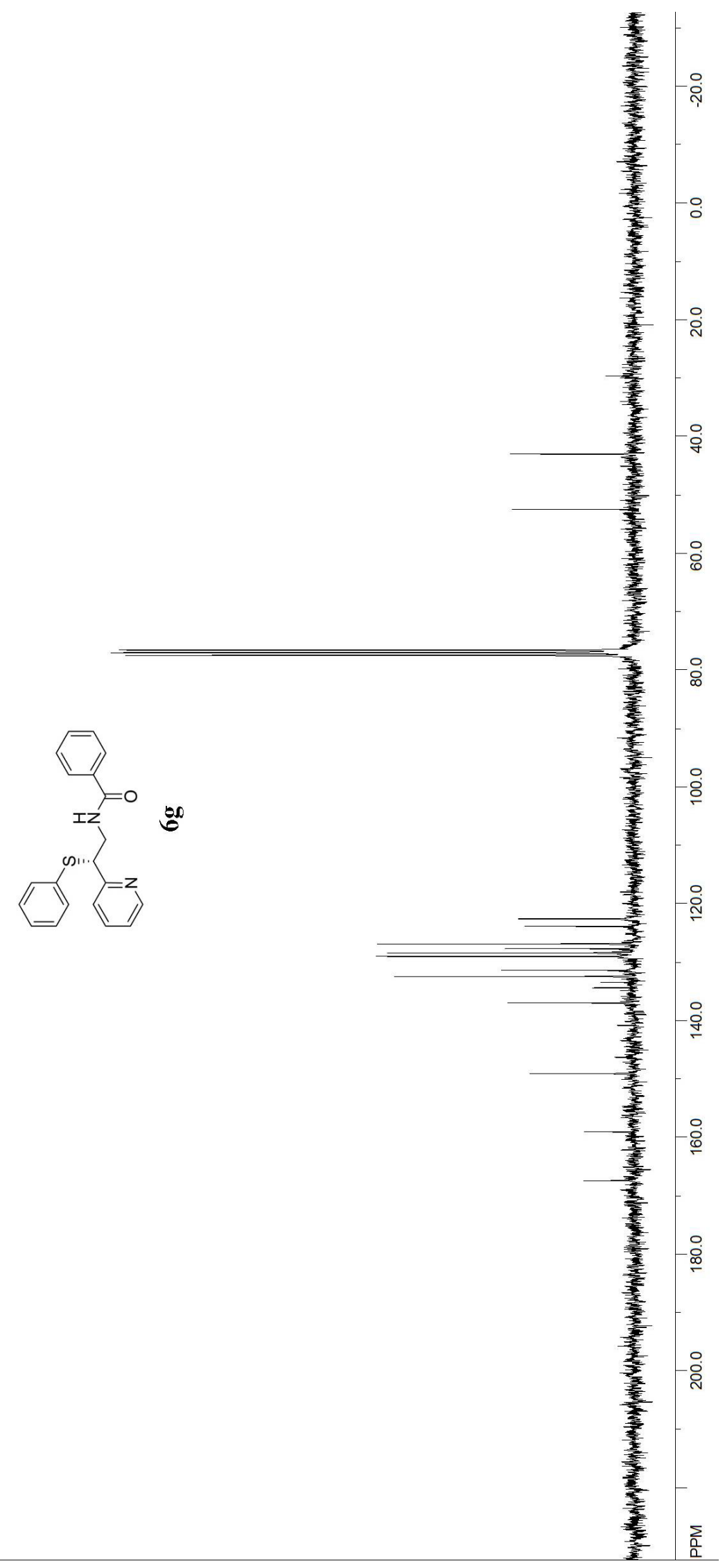




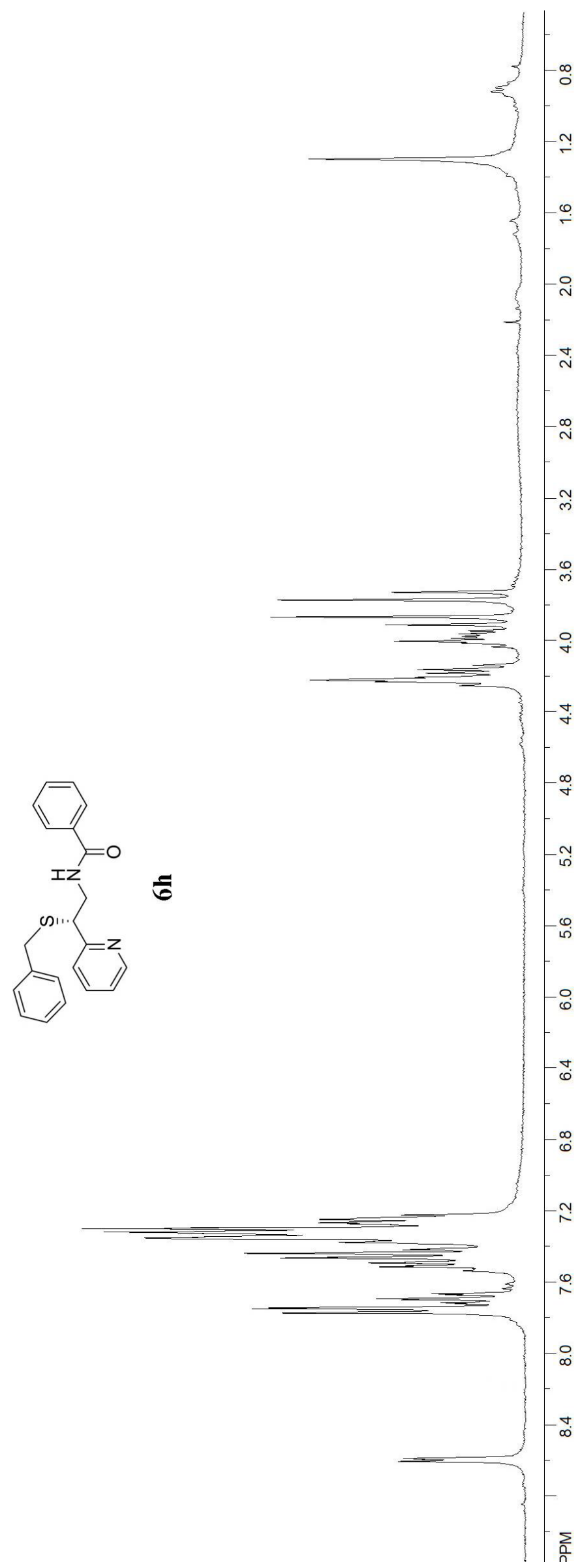




$$
1
$$



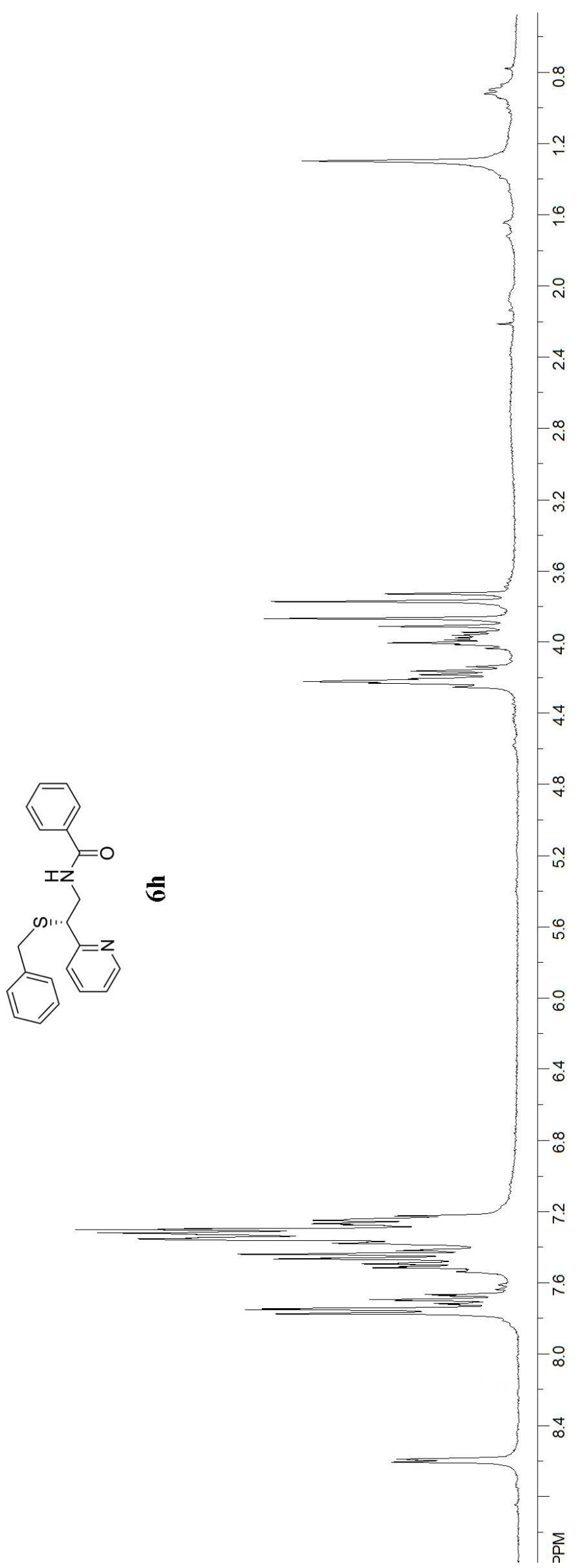


$$
1
$$




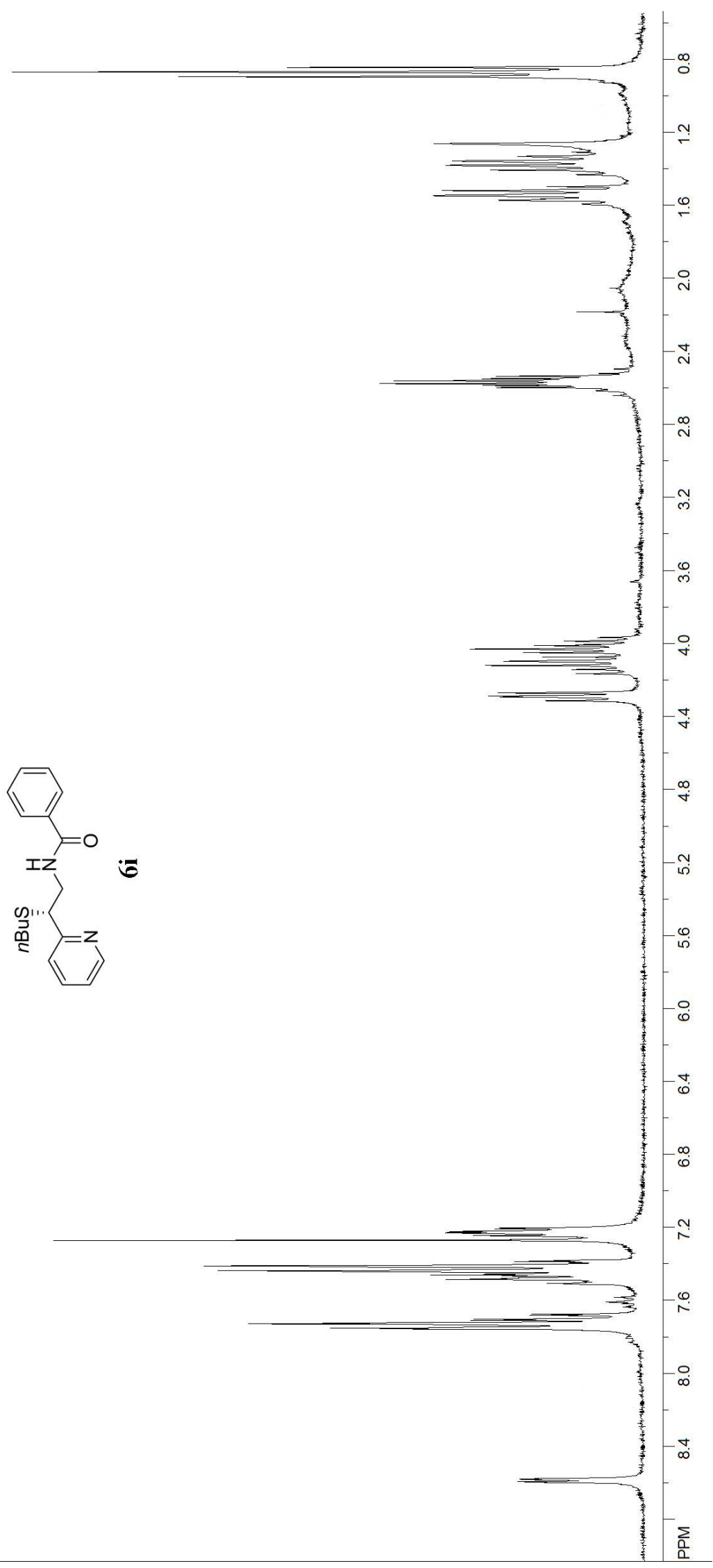




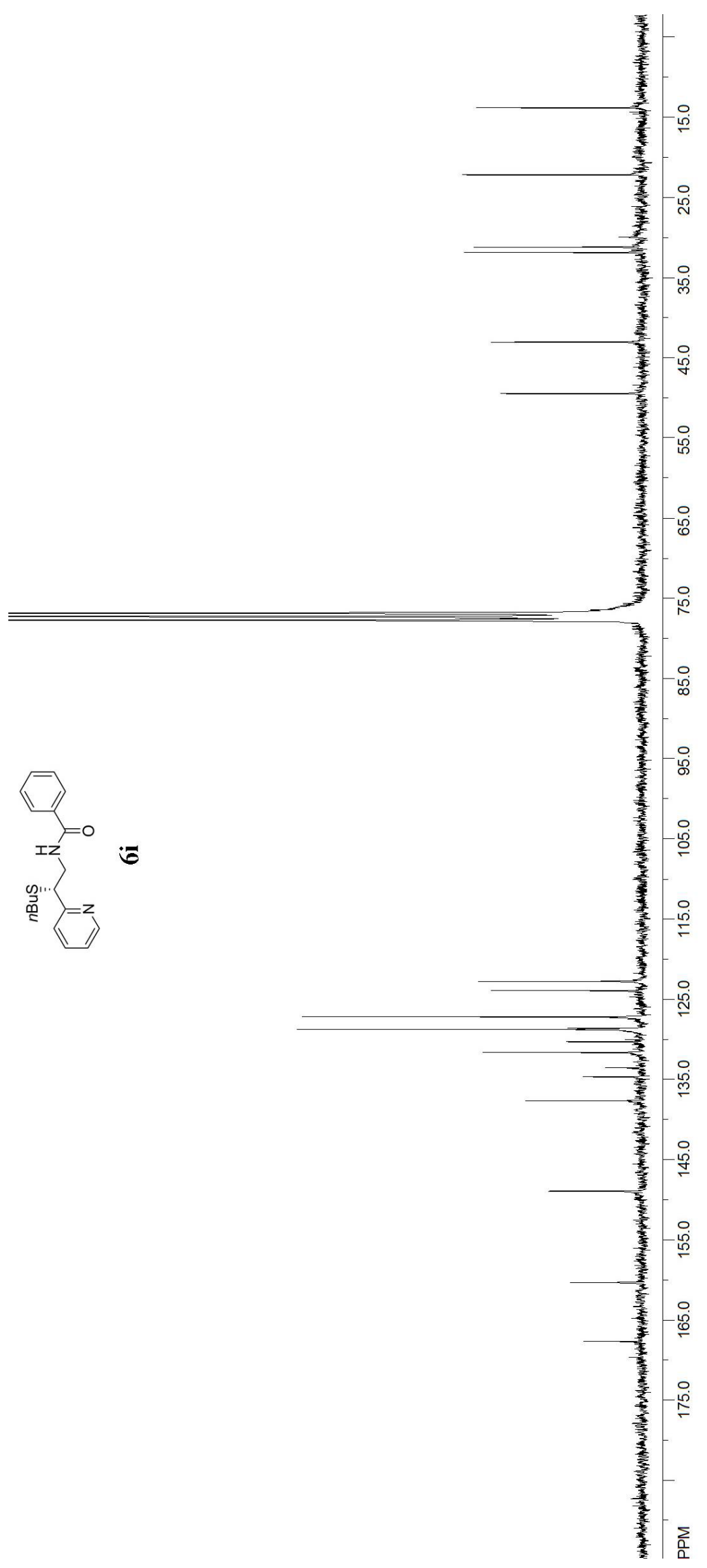




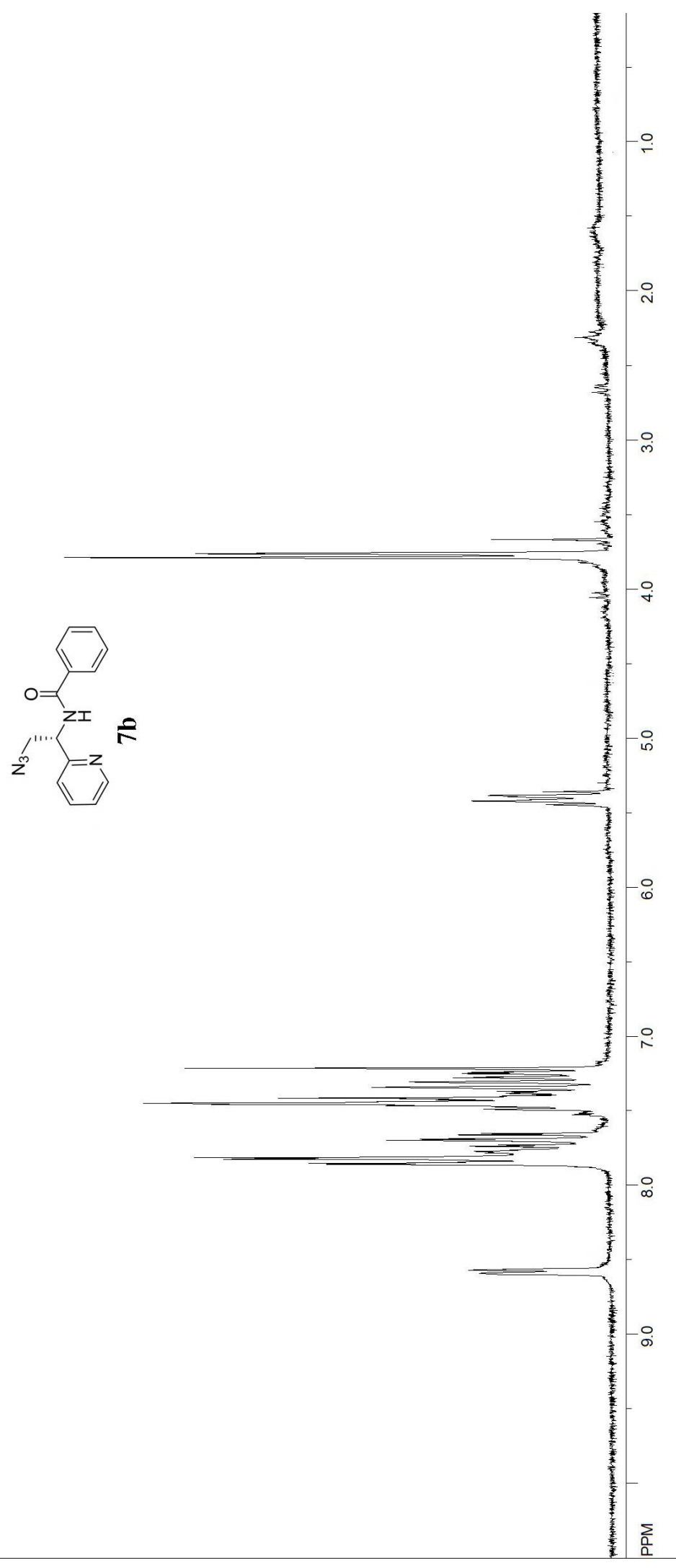




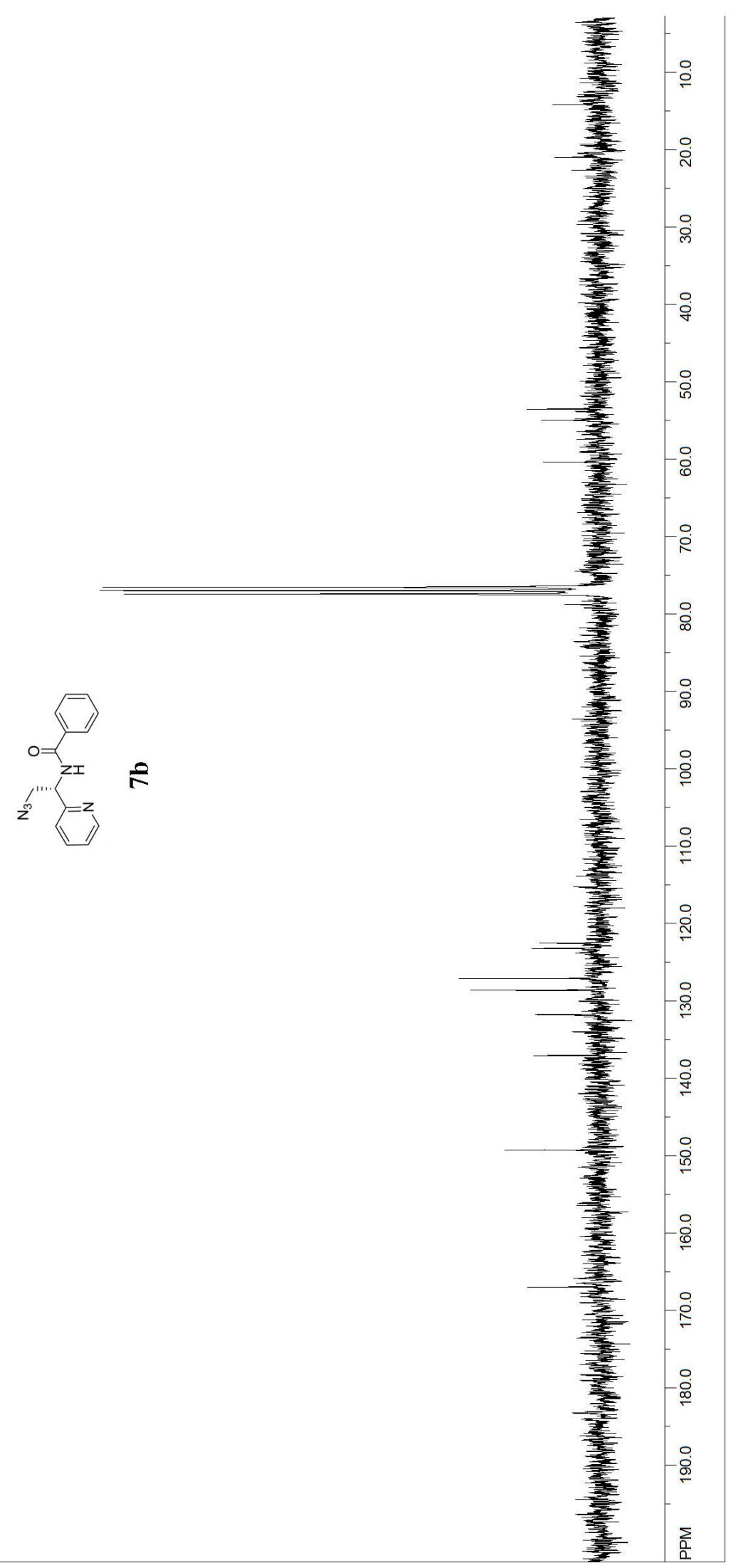




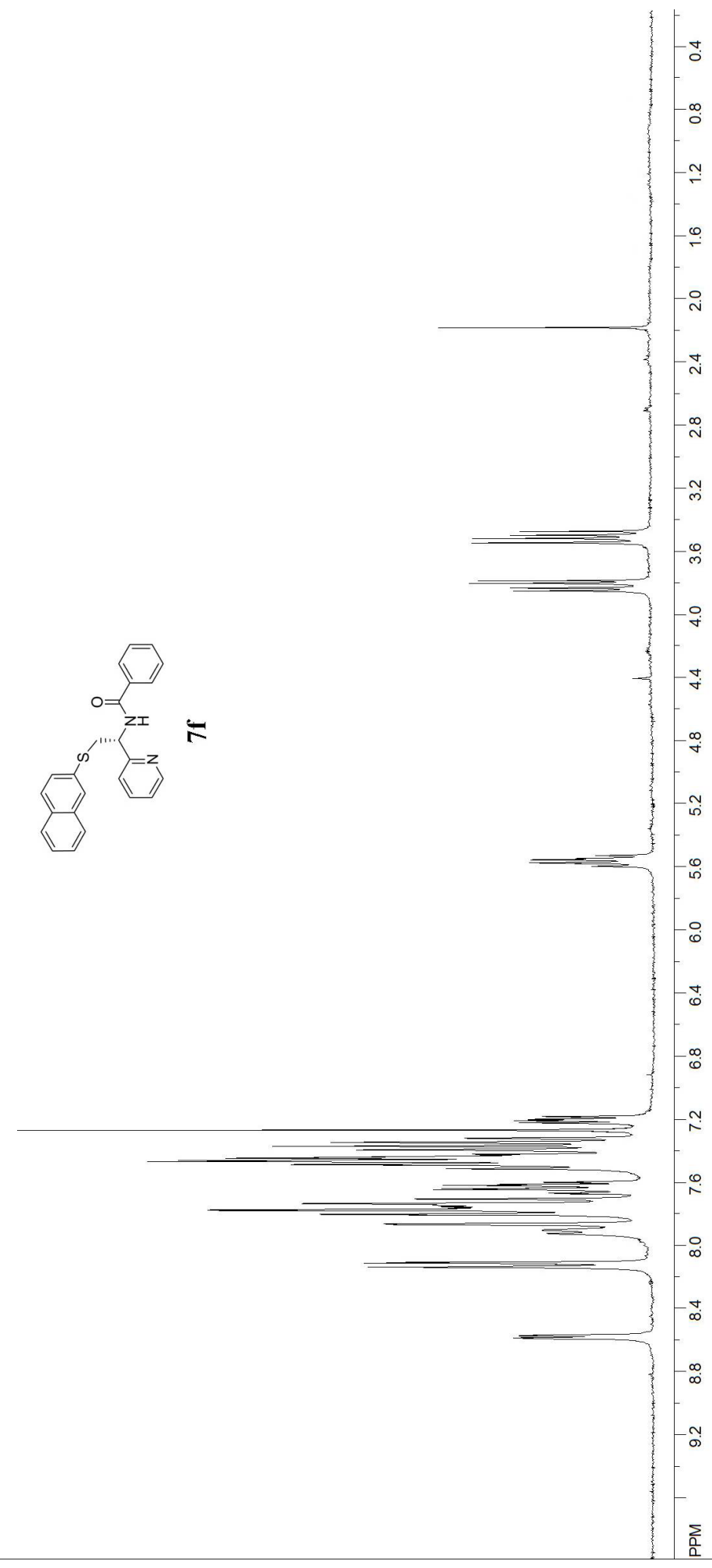




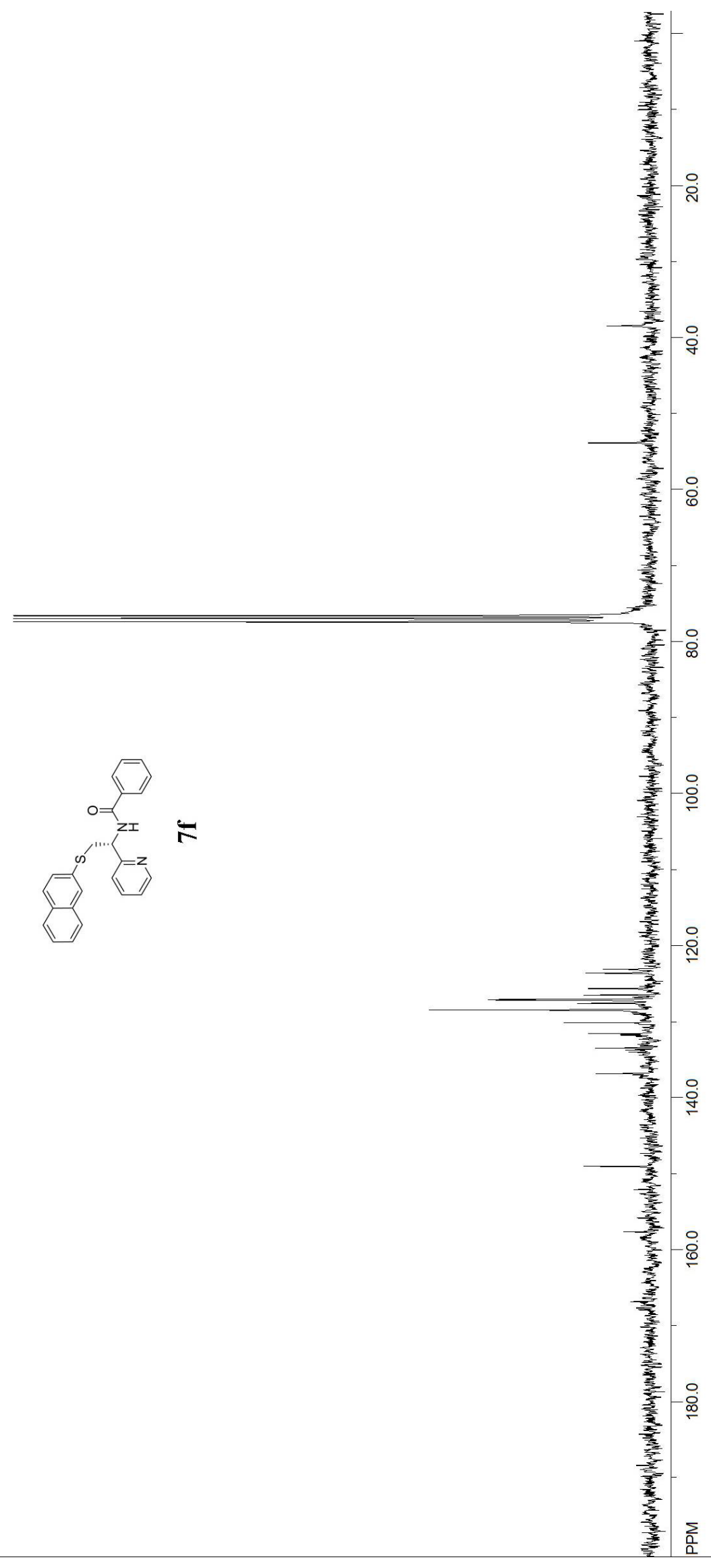




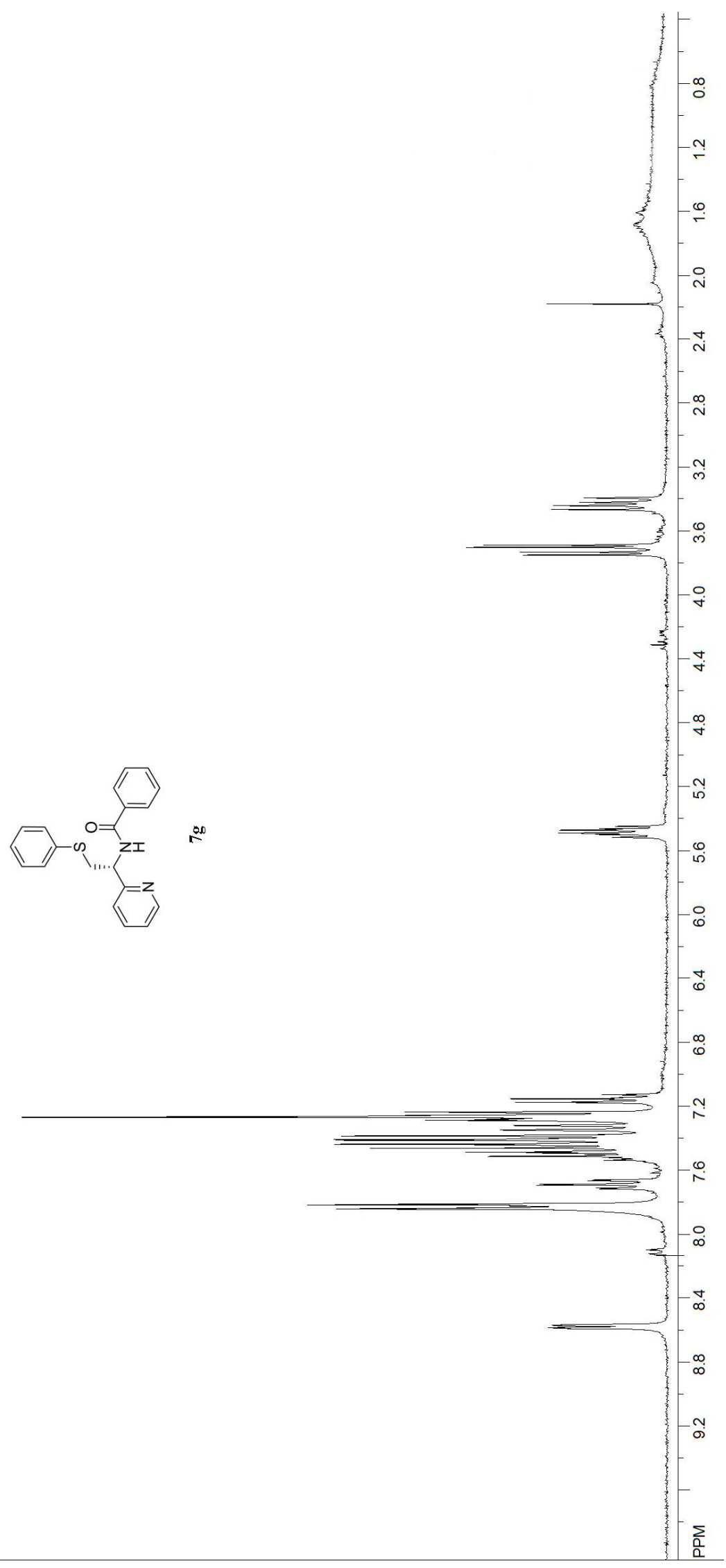




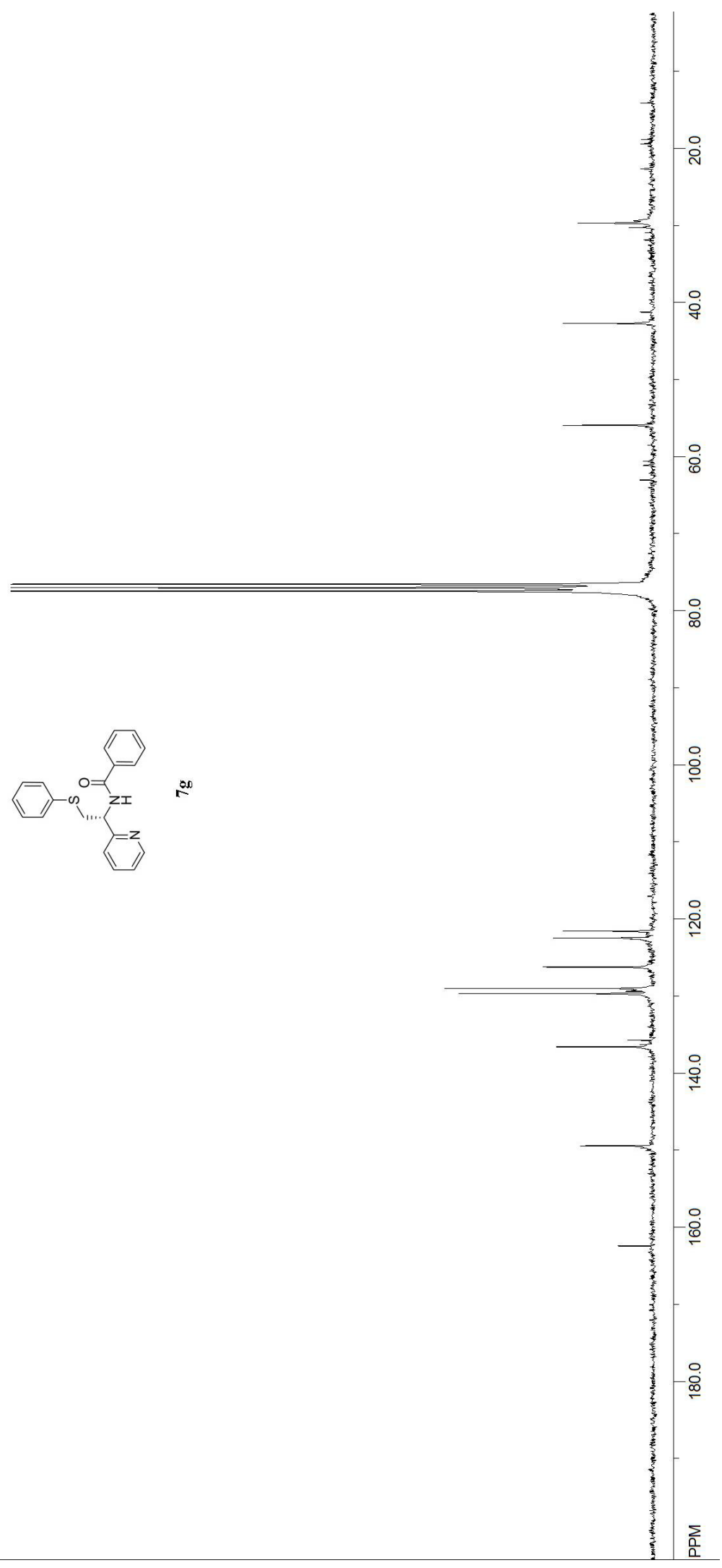




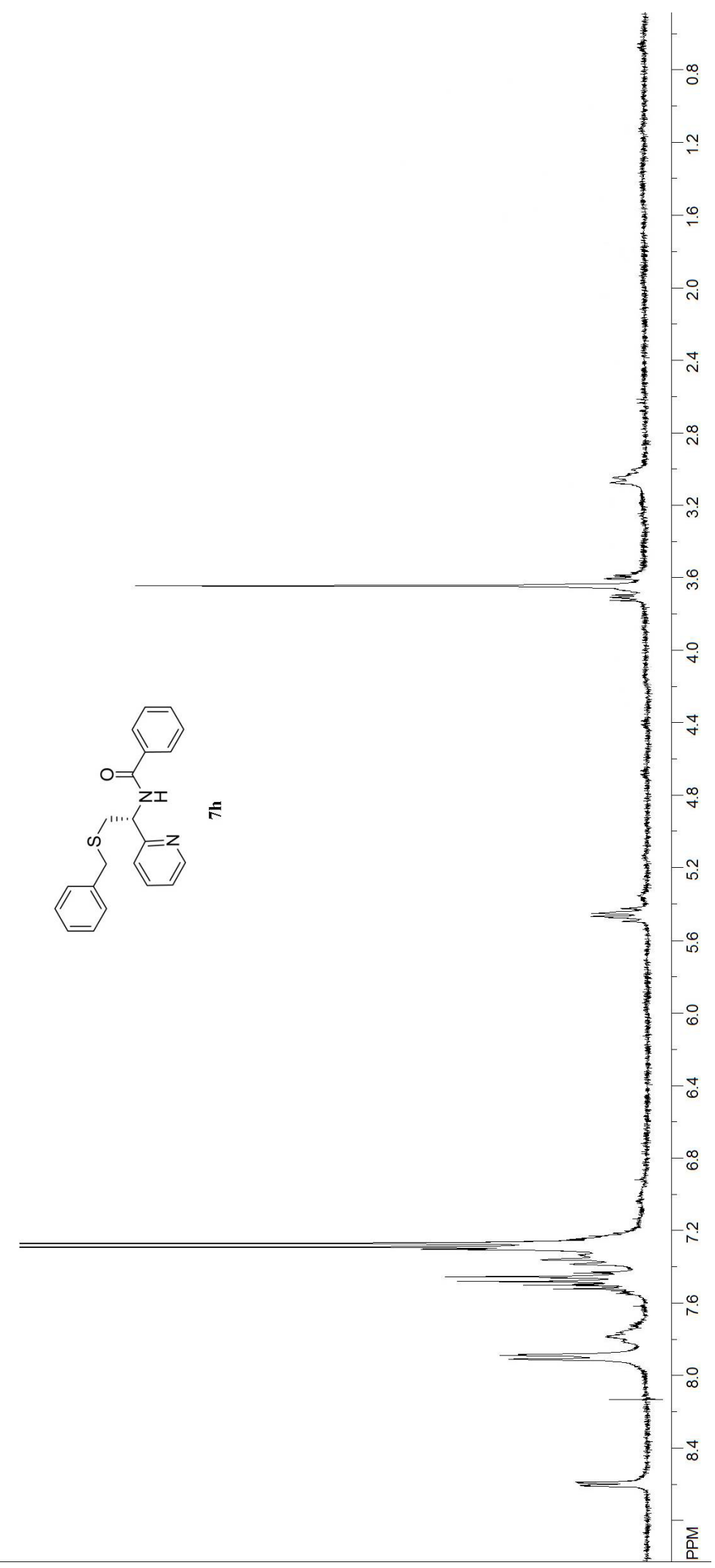




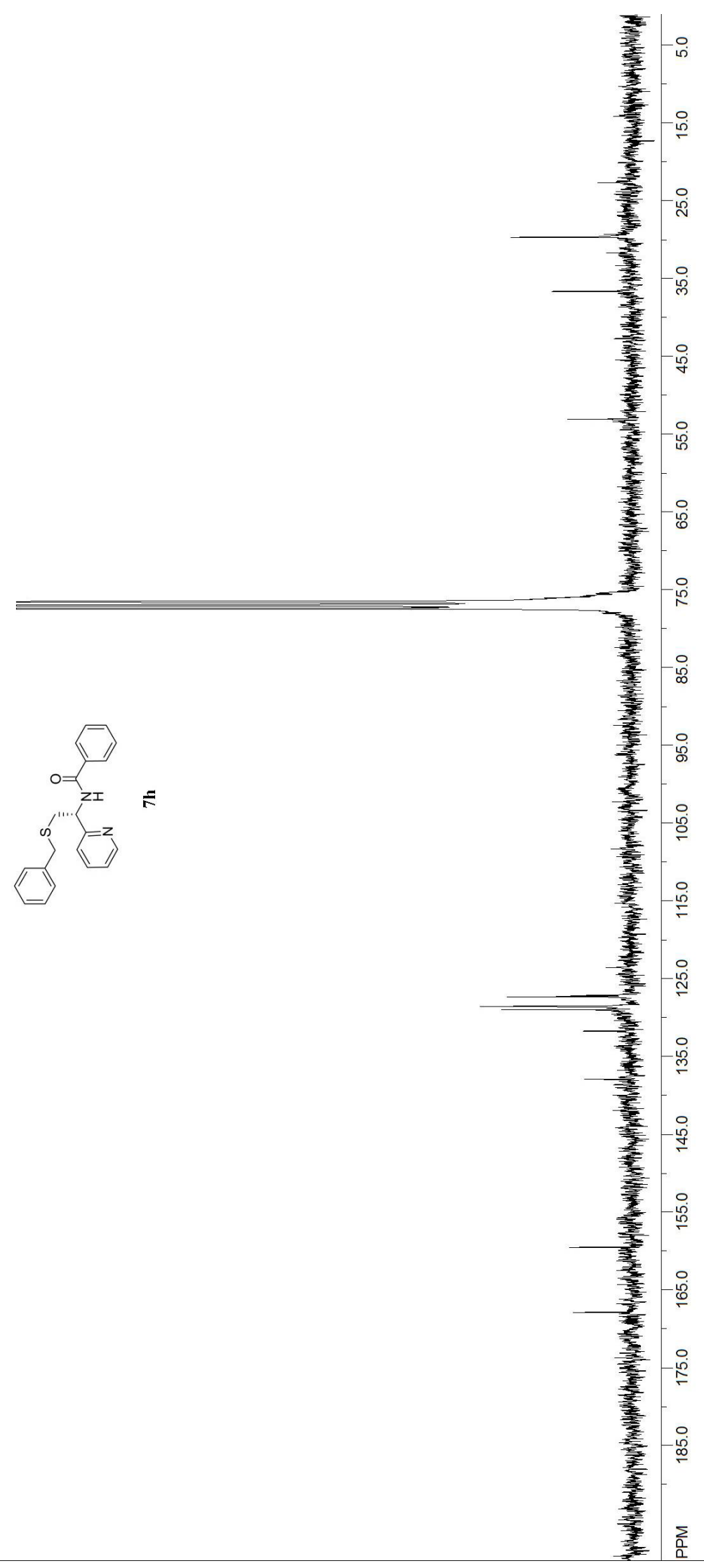



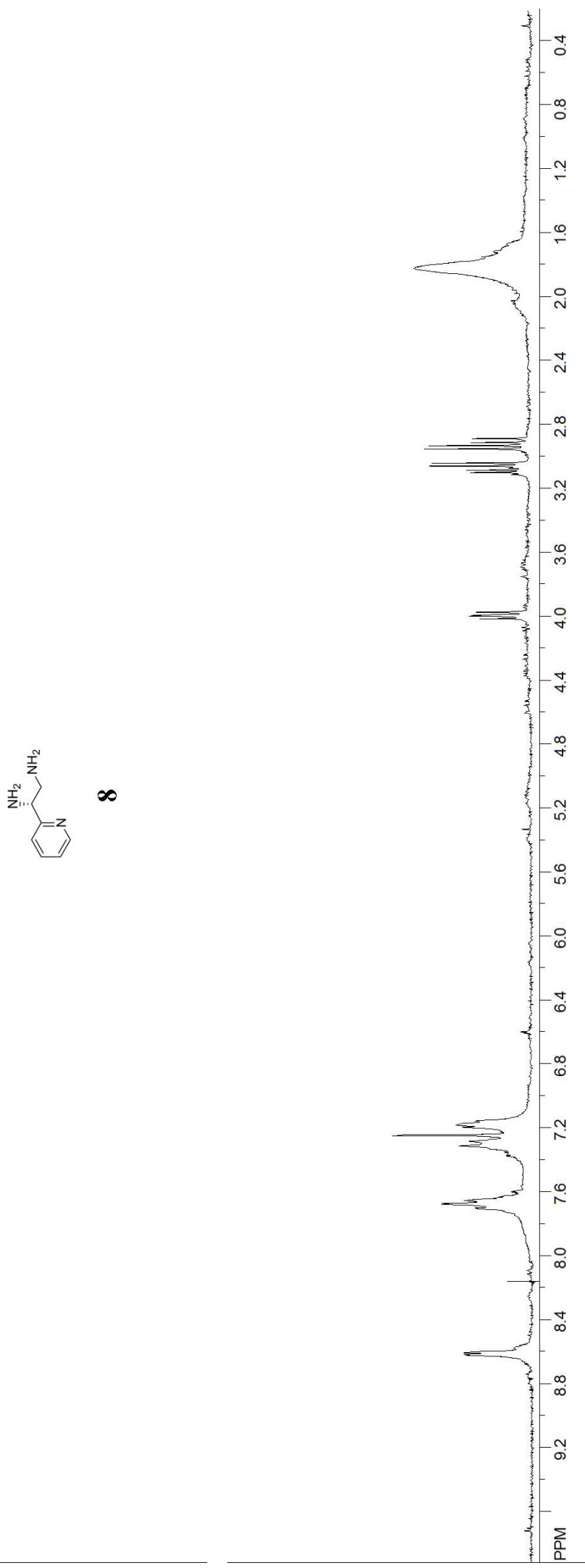


$$
t
$$

